PRI MCED Discussion Paper Series, No. 44

\title{
Substitution Bias and External Validity: Why an \\ Innovative Anti-poverty Program Showed no Net
}

Impact

\author{
Jonathan Morduch, Shamika Ravi, \\ and Jonathan Bauchet
}

July 2013 


\title{
Substitution Bias and External Validity:
}

\section{Why an innovative anti-poverty program showed no net impact}

\author{
Jonathan Morduch, New York University* \\ Shamika Ravi, Indian School of Business \\ Jonathan Bauchet, Purdue University
}

July 2013

\begin{abstract}
The net impact of development interventions can depend on the availability of close substitutes to the intervention. We analyze a randomized trial of an innovative anti-poverty program in South India which provides "ultra-poor" households with inputs to create a new, sustainable livelihood. We find no statistically significant evidence of lasting net impact on consumption, income or asset accumulation. Instead, income from the new livelihood substituted for earnings from wage labor. A very similar intervention made a large difference elsewhere in South Asia, however, where wage labor alternatives were less compelling. The analysis highlights the roles of substitution bias and dropout bias in shaping evaluation results and delimiting external validity.
\end{abstract}

JEL codes: O1, J2, C1, I3

* Corresponding author. NYU Wagner Graduate School of Public Service, 295 Lafayette Street, 2nd Floor, New York, NY 10012, USA. Phone: (212) 998-7515; Fax: (212) 998-4162; Email: jonathan.morduch@nyu.edu. 


\title{
SUBSTITUTION BIAS AND EXTERNAL VALIDITY:
}

\section{WHY AN INNOVATIVE ANTI-POVERTY PROGRAM SHOWED NO NET IMPACT}

\author{
Jonathan Morduch, Shamika Ravi, Jonathan Bauchet
}

\section{Introduction}

The poorest of the poor face broad challenges. The traditional policy response is to create safety nets, with publicly-funded income transfers that provide a basic standard of living. The transfers are designed for survival, not economic advancement. BRAC, a globally-recognized NGO based in Bangladesh, sought to improve on the standard safety net idea by instead giving poor households a larger quantity of resources in a shorter period of time. BRAC coupled financial transfers with training and assets to help recipients build a new livelihood as a self-employed, small-scale entrepreneur (Matin and Hulme 2003). The bet is on the possibility of "graduation" from a life of extreme poverty into a life of economic self-sufficiency, an idea with roots in the economics of poverty traps (Bowles et al. 2011, Sachs 2005). BRAC created the model in Bangladesh, and donors have supported its replication and evaluation in India, Pakistan, Ghana, Ethiopia, Yemen, Haiti, Peru, and Honduras. ${ }^{1}$

We design and implement an RCT to analyze the replication of a similar program in the South Indian state of Andhra Pradesh, implemented by the NGO arm of SKS, a large commercial microfinance institution. Despite expectations that the intervention could be transformative (SKS 2011), a year after the intervention ended there were no statistically significant net impacts on average household income, consumption, asset accumulation, nor use of financial services. We

1 Information on all sites is available at http://graduation.cgap.org/. The evaluation of the replication in West Bengal has followed on a similar timeline to this one. 
show that the program was implemented as designed, but it caused substitution away from paid wage employment, erasing the net economic and social impacts on the treatment group.

The substitution mechanism is a version of "substitution bias" (Heckman et al. 2000). Concerns with external validity tend to take two forms. First, difficulties when generalizing in the face of population heterogeneity (e.g., Alcott and Mullainathan 2012, Heckman and Vytlacil 2007, Eldridge et al. 2008), and, second, difficulties when there are varied complementary inputs - including differences in infrastructure, transportation, government programs, and economic conditions (Cartwright 2010).

Substitution bias is a third, less appreciated class of problems for external validity. It receives no mention on the extensive list of biases described in a well-cited toolkit on RCTs in developing countries (Duflo et al. 2008); nor in essays that cover problems of extrapolation from RCTs (Deaton 2010). Yet, optimization across alternative economic mechanisms, both formal and informal, is a mainstay of development theory (Bardhan and Udry 1999).

One reason that substitution bias may be under-recognized is that the formalization was formulated in a particular way for a particular problem. In parallel to the present context, Heckman et al. (2000) seek to explain why a promising social experiment did not deliver the expected positive net impacts. The Job Training Partnership Act (JTPA) was a large federal program in the U.S. that provided job skills training services and employment referral services to disadvantaged adults and youth. It was evaluated as a randomized controlled trial, with treatment groups given exclusive access to the JTPA. But Heckman et al. (2000, Table 1, p. 654) show that many people in the control group received training from other programs, getting training with similar quality and duration. In addition, some members of the treatment group dropped out of the federal training program. The substitution and drop out combined to create a situation in 
which the gap in actual training received between treatment and control groups was much smaller than 100 percent (the scenario in which the control group would not receive any training): it fell as low as 19 percent for some groups. The lower gap reduced the measured net effect of training on earnings and employment.

As a result, the JTPA social experiment could accurately measure the net effect of the particular program, but not (without strong assumptions) the effect of training. Policymakers, however, benefit from having answers to both questions when extrapolating lessons to other settings - and the latter can sometimes be more important than the former. Heckman et al. (2000) show that the private net return to training turns out to be large, even though the program itself delivered mixed results. In this line, they conclude that:

Our evidence suggests that experimental evaluations cannot be treated as if they automatically produce easily interpreted and valid answers to questions about the effectiveness of social programs. Reporting the experimental estimates by themselves without placing them in the context in which treatments and controls operate invites misinterpretation. (p. 689)

To extend their analysis, it's helpful to generalize in two directions. Heckman et al. (2000) describe substitution bias in a way that follows from the actual JTPA experience: the treatment group received a useful program, and members of the control group found an alternative way to get similar services. In drawing the parallel to the experiment in India, it helps to re-formulate the JTPA substitution mechanism: both the treatment group and control groups have ways to get training services, but the treatment group was offered the JTPA training 
program as well (and many substituted into it). The outcomes in both formulations are similar, as is the implication for how RCT results are interpreted, but the controls act in the first case and the treatments makes the switch in the second.

One parallel is evaluations of microfinance, in which most poor households in developing countries already have access to some forms of finance, even if they are mostly informal (e.g., moneylenders, community-based savings groups, and loans from relatives; Collins et al, 2009). The introduction of a formalized microfinance program will induce some people in the treatment group to substitute away from these financial arrangements. Because of substitution bias, an impact evaluation would thus show the net benefit of access to the microfinance program, but will not provide answers to other relevant questions like the size of the private net benefit of access to finance in general. Das et al (2013) provide a budget-driven example; they document how households given educations grants re-optimize their spending to fully offset the grants, such that anticipated increases in school funding fail to yield significant improvements in students' test scores.

The second way to generalize the substitution bias mechanism is to apply the idea to substitution between any alternative activities that can be used to achieve similar ends. In the case of Heckman et al. (2000), the issue was that nearly identical training opportunities were available to the treatment and control group members. In the South Indian case, the options are less similar, but the basic mechanism remains. The issue in our study period was that the option to work as a wage laborer was increasingly compelling as wages increased rapidly in South India (Clément and Papp2012), and members of the control group benefited considerably. Members of the treatment group had to forego much of those gains if they participated fully in the antipoverty program and got on a path to self-employment. Both wage labor and self-employment 
are alternative job strategies to obtain stable livelihoods, and any one person has difficulty doing both simultaneously.

The evidence shows that the SKS anti-poverty intervention directly created income gains by promoting livelihoods in the livestock sector (almost 90 percent of participating households chose livestock rearing as their enterprise). On average, income increased by 65 percent in the treatment group between the baseline survey and the endline survey.

But control group income increased by a similar amount (67 percent). Two developments can explain why the treatment and control groups had similar outcomes, yielding no net impact. First, gains from participation in the treatment group were offset by foregone wages from agricultural labor. Time constraints made it hard to both work fully as a wage laborer on other people's farms and to take care of one's own livestock as part of the SKS program. On average, households that participated in the anti-poverty program increased monthly per capita income from livestock by 53 Rupees more than control households (about US\$3.20 in PPP conversion, or 17 percent of the average baseline monthly per capita income), but the control group increased monthly per capita income from agricultural wage labor by 51 Rupees more than the treatment group (calculations from Table 3). The relative gain was undone by the relative loss. ${ }^{2}$

Second, about 40 percent of households who elected to receive an animal from the program did not own any animal at the time of the endline survey. The evidence suggests that these households chose to sell their animal(s), pay down outstanding debt, and take advantage of opportunities in the labor market. ${ }^{3}$ This mechanism corresponds to "dropout bias", a

2 The market exchange rate at the baseline (October 2007) was 39 rupees per US\$1. At the endline (October 2010), it was 44 rupees per US\$1.

3 On average, treatment households who did not own an animal had a lower total income per capita than treatment households who held on to their animal. The endogenous nature of the decision to keep or sell animals prevents us from interpreting this difference causally, but we note that households who sold their animal - likely those who were not doing as well as they hoped with livestock rearing - had higher income from wage labor than those who held on to their animal. 
phenomenon related to substitution bias, in which households with compelling alternative opportunities drop out of the program to pursue those alternatives (Heckman et al. 2000). Dropout bias differs from attrition bias, since households fail to follow through on the programs' expectations, but they stay in the sample.

These possibilities for substitution between programs and alternatives are growing in India. India's recent economic growth has brought overlapping programs rolled out by banks, NGOs and the government. Of particular note is the ambitious National Rural Employment Guarantee scheme (NREG), which swept through our study region, guaranteeing (on paper) 100 days of employment per year per household, paid 115 Rupees per day on average (Ministry of Rural Development of the Government of India 2011). At the time of the baseline, 34 percent of all households in our sample (across treatment and control groups) participated in the NREG scheme; by the endline, 81 percent did.

The most important substitution that we find is not with NREG participation directly but with participation in the agricultural labor market broadly. At a national level, the National Sample Survey Organization (NSSO) data reveal a 27 percent increase in real wages for casual labor in rural India, between 2004 and 2010. The wage increase aligns with a broader shift out of self-employment and into paid labor. The NSSO calculated a drop in self-employment from 56 percent of the labor force to 51 percent between 2004 and 2010, while casual labor rose from 28 percent to 33 percent and wage labor rose from 15 percent to 17 percent. The SKS ultra-poor program, which was designed to promote self-employment in a population dominated by wage labor, can be seen as fighting against these trends.

All else the same, the net impact would have likely been greater in another region, with a less tight labor market or where wage labor is less prevalent. The version of BRAC's program 
implemented in West Bengal showed large positive net benefits to livestock income and entrepreneurial activities, with limited evidence of the substitution that marked the SKS program. One main factor, we suspect, is that in our site over 90 percent of the households cited wage labor as a main income source before the program started, versus only about half in West Bengal (Banerjee et al. 2011, Table 4). Similarly, a new round of BRAC's program evaluated with an RCT in Bangladesh shows that the program led to a large increase on average income. In BRAC's program, about half of ultra-poor households were involved in any wage employment, and only 28 percent were exclusively working in wage employment (Bandiera et al., 2012).

These programs followed a similar design and were instituted and evaluated through coordinated (but independent) studies. We cannot rule out, however, that some of the differences in net impact are due to elements of program design that were adapted locally. Most important, while the overall level of household support in the SKS replication was comparable to that in the other programs, the composition differed. In the SKS replication, households did not receive a consumption stipend, unlike in other locations; instead, a greater share of funds went to pay for the asset and its upkeep.

Recognition of substitution bias re-frames conclusions about what the anti-poverty program achieved and what it might contribute elsewhere. Even as efforts proceed to make evaluations more central in development policy, attention to external validity is mixed and incomplete, and there's no consensus about what should be considered a generalizable "proven impact." The findings here affirm the importance of rigorous evaluations while highlighting the conditional nature of impact results. 


\section{Background and Data}

The Ultra Poor Program (UPP) in South India aims to establish microenterprises with regular cash flows, which would enable ultra-poor households to grow out of extreme poverty, and eventually gain access to microfinance in order to maintain and expand their economic activity. The pilot program was implemented by Swayam Krishi Sangam (SKS) ${ }^{4}$ in198 villages of Medak district in the state of Andhra Pradesh, one of the poorest districts in India. The program we evaluate has now been introduced in the state of Orissa.

The program targets the poorest households which have few assets and are chronically food insecure. It combines support for immediate needs with investments in training, financial services, and business development. Funds to partially defray the costs of livestock rearing are transferred in the SKS version, but, unlike other program designs, no direct consumption support is provided. The overall cost of the program, though, is in line with other pilots. The aim is that within two years ultra-poor households are equipped to help themselves "graduate" out of extreme poverty. The approach is thus sometimes called a "graduation program."

The replications were inspired by the success in Bangladesh of BRAC's "Challenging the Frontiers of Poverty Reduction - Targeting the Ultra Poor" (CFPR-TUP) program, which reaches about 300,000 households in Bangladesh. BRAC estimates that over 75 percent of the beneficiaries in Bangladesh are currently food secure and managing sustainable economic activities. The program there has been studied extensively using non-experimental techniques(Emran et al. 2009, Krishna et al. 2012, Mallick 2009, Matin and Hulme 2003), with most studies finding positive impacts on income, consumption and asset accumulation of poor households. A randomized controlled trial evaluation of BRAC's program is also being

4 The program was implemented by SKS NGO, an entity distinct from SKS Microfinance. 
conducted in Bangladesh, and we compare our findings with preliminary findings from that study (Bandiera et al. 2012).

The idea of expanding this type of interventions gained ground through concern that ultra-poor households remain outside most programs aimed at poverty reduction. Even within the context of microfinance, it has been noted that poorer households do not gain significantly from access to credit (Morduch 1999). Many government schemes that target "below the poverty line"

households have failed to do so due to mistargeting (Drèze and Khera 2010, Jalan and Murgai2007, Ministry of Statistics and Programme Implementation of the Government of India 2005). Banerjee et al. (2007)find that the poorest are not any more likely to be reached by government programs than their better off neighbors.

\section{SKS's Ultra Poor Program}

The program as implemented by SKS is an 18-month intervention aimed at extremely poor households, identified through detailed participatory rural appraisals and village surveys. Households have to meet five criteria to be eligible for the program: (i) not including a male working member, (ii) scoring less than a threshold number on a housing condition scorecard, (iii) owning less than one acre of land, (iv) not owning a productive asset, and (v) not receiving services from a microfinance institution. The housing condition scorecard takes into account characteristics of the house such as its size, building material, and electricity and water access.

The program comprises four main components: 1) an economic package designed to provide self-employment and spur enterprise development, 2) essential health-care, 3) social development, and 4) financial literacy. The economic package for enterprise development involves a one-time asset transfer, enterprise-related training, cash stipend for large enterprise- 
related expenses, and the collection of minimum mandatory savings. It starts with the selection of an income-generating activity by the household, from a menu of local activities such as animal rearing (mainly a buffalo or goats) or horticulture nursery. Non-farm activities, such as tea shops, tailoring, or telephone booths, are also available. Once the household has selected an activity, it undergoes training sessions where one ultra-poor member, usually the woman head of household, is taught skills pertaining to the specific enterprise she has chosen and how to find additional help when needed (for example, veterinary care). After the training is completed, the specific asset or in-kind working capital is procured and transferred to the household. A mandatory weekly savings is required of all households, once the asset begins to generate cash flow, such that households save at least $\$ 16$ by the end of the program in order to "graduate."

On average, the program cost US $\$ 357$ for each participant (Table 1). The costs of the asset and stipend given to help households meet enterprise-related expenses represent 42 percent of the total program cost. Capacity building (training) and implementation are the next two biggest costs (30 percent and 26 percent, respectively). The remaining costs were incurred at the targeting phase.

A large majority of households in the program chose to rear livestock as their enterprise: 55 percent of all households chose a buffalo, 31 percent chose goats, and three percent chose donkeys, pigs or sheep. The next most popular choice was non-farm business, an activity elected by seven percent of households. Finally, almost 3.5 percent of households used the program's grant to purchase land, earning an income from leasing it out for agricultural production. All analyses are performed with the entire sample of households, because the sample of households which chose non-farm businesses and land lease is too small. 
The second component of the program is the provision of essential primary health-care support. This is a combination of preventive training and techniques, and on-the-spot coverage. The health program is divided into the following: a) monthly visits by a field health assistant to each member, documenting the health status of the family and providing care or referrals as needed; b) health screening and information awareness camp hosted with support from government doctors and health focused NGOs; c) monthly information session conducted by the health assistant on topics such as contraception, pre- and post-natal care, sanitation, immunization, tuberculosis and anemia; and d) one or two program member in each selected village is trained by a doctor on basic health services. This member is equipped with basic medicines (available free of cost from the government) and a knowledge of when to recommend a case to a doctor or hospital, and serves as the touch-point for other members.

The third component of the program is social development. It involves measures aimed at building social safety nets in the village, such as a solidarity group and a rice bank, and connecting participants to existing public safety nets. Group solidarity is encouraged through weekly meetings where members discuss common concerns and solutions. A rice bank is created by members depositing a handful of rice every day, which can be drawn upon by member households at no interest.

The financial literacy component of this program involves basic training in budgeting exercise and setting financial goals. There is also an emphasis on accumulating savings and reducing reliance on moneylenders.

After18 months, SKS stops conducting the weekly meetings, collecting the weekly savings from members and organizing health camps in the treatment villages. The asset becomes a complete responsibility of the household with no enterprise-supporting stipend or advisory 
support from SKS. By the end of the program implementation, households are supposed to "graduate" out of extreme poverty. The graduation criteria included having children in school, being "food secure" for at least 30 days, creating an income generating activity beyond wage labor, and accumulating more than $\$ 16$ in savings (800 Rupees). Reflecting the program's holistic approach, household must also have gained knowledge about social and health issues, and become aware of any available government programs.

Our findings on the net impact contrast with broadly positive impacts found in parallel studies in West Bengal, India (Banerjee et al. 2011) and the original BRAC program in Bangladesh (Bandiera et al. 2012). Why do the results differ? The most immediate possibility is program failure (a failure to effectively implement the program). Taken on its own terms, however, the program was not a failure. SKS implemented a Client Monitoring System to track the progress of program participants throughout the 18 months of the program. (No data was collected on households in villages assigned to the control group in the randomized experiment.) The system was developed by BRAC Development Institute, a research arm of the NGO BRAC in Bangladesh involved, among other things, in the evaluation of BRAC's own TUP program. Three rounds of data were collected during the implementation of the program (September 2008, January 2009 and June 2009), and an additional round was collected six months after the end of implementation, in January 2010. The Client Monitoring System relied on SKS program officers electronically collecting data on the participants that they managed, and covered a wide range of indicators such as asset ownership, savings behavior, amount and use of stipends, other sources of income, illnesses, and food security.

The Client Monitoring System shows that the average cost of the program reached US\$357 for each beneficiary, covering an asset with which to start a small enterprise, a stipend 
covering enterprise-related costs, and 18 months of peer-to-peer skills training, basic healthcare and saving promotion. As evidenced by detailed results described below, participating households received the assets and services as promised, started new livelihoods and generated income from it, and proceeded toward meeting the goal of "graduation." According to the Client Monitoring System, 97 percent of participants reached that goal.

\section{Data}

Most of our analyses rely on detailed quantitative data collected from3,485 individuals, living in 1,064 households across 198 villages in Medak district, in three waves of surveying between 2007 and 2010.

The baseline survey was conducted between August and October 2007. Detailed information was collected on socio-demographic characteristics of the households, which included religion, caste, family type, size of household, age, marital status, disability, education, occupation, and migration details. Information was also collected on the household's living conditions, including characteristics of the house, source of drinking water, sanitation and source of fuel. Participation in government schemes (employment, pension, housing, training, credit and subsidized basic goods) was recorded. The baseline survey also included measures of asset ownership, use of time, women's social status and mobility, and political awareness and access. Health information collected included data on physical health, hygiene habits and mental health conditions of household members. In addition, we have gathered details of household monthly consumption expenditure, income and other financial transactions of the household. We also collected details on social standing of the household within the community and future aspirations of the household members. 
Following the baseline survey, we randomly assigned 103 villages to the treatment group and 95 to the control group. The 103 treatment villages included 576 households (54 percent of the total sample) who were offered the treatment. ${ }^{5}$ Of these, 426 households participated in the program and 150 households declined to participate. In all our analyses, these 150 households are counted as part of the treatment group (to measure the intention to treat estimates). The most common reasons for not participating in the program were "not interested in taking asset" (52 percent), migration (33 percent) and having access to microfinance loans (11 percent). ${ }^{6}$ "Microfinance" loans do not include loans from self-help groups; almost 50 percent of households which reported having outstanding loans in the baseline had one or more loans from self-help groups. SKS realized post-targeting that 19 households initially deemed eligible for the program had existing access to microfinance products. Since the design of UPP aims to "graduate" people into microfinance, households that already enjoy access are deliberately left out of the program.

A midline survey was conducted for the entire sample between April and September 2009 , immediately at the end of SKS's presence in the villages and about 18 months after treatment households received their asset. Since the enterprise training and subsequent asset transfer took almost six months to implement, the midline survey was conducted over a longer period than the other two survey waves. As a result, the effects of the seasonality of economic activities, particularly present in the agricultural communities where the program was implemented, influences the measurement of important outcomes in the midline survey. Because

\footnotetext{
6. Subsequent interviews with some of the households that refused to take part in the program revealed that "not interested" could imply a lack of entrepreneurial ability or self-confidence, or simply having access to higher wages as construction workers in the nearby township. Seasonal migration for work is a common feature of the labor market in this part of rural India.
} unlikely.

5. Note that with 5.6 households per village participating in the treatment, general equilibrium effects are 
the impacts of interest are the program's long-term impacts, and to compare outcomes measured at similar periods of the year, we focus our analyses on baseline and endline surveys.

The endline survey was conducted for the entire sample of households almost exactly three years after the baseline, in October and November 2010. In the endline wave, we were able to reach 1,011 of the baseline households. The endline survey included the same questions as the baseline survey, with the addition of two new sections that collected detailed information on participation in the NREG scheme, including number of household members working in the scheme, number of days worked, and payment received for work in the scheme. The other additional section collected height and weight data for children under 10 years of age living in the household.

The rate of attrition between baseline and endline surveys was five percent. We compare in Appendix Table 1 the means of various household characteristics between households that we successfully reached in the endline survey and those that we could not. The households that we were not able to follow up in the endline survey have an older and more literate head, but there are no significant differences in family size, income, expenditure, asset ownership, use of financial services, or participation in government schemes. Appendix Table 1 shows that the difference in attrition rates between treatment and control groups is not statistically significant. We tested whether attrition was different for treatment and control groups by regressing an indicator variable equal to one if the household was an attriter and zero otherwise on a treatment indicator, the five control variables, as described in the Analysis Strategy section below, and the interaction of the treatment dummy and each of the control variables. An F-test of the joint significance of the treatment dummy and the five interactions confirms that being assigned to the treatment group does not significantly predict long-run attrition $(F=0.51, p$-value $=0.802)$. 
Most of the analyses compare the baseline data to the endline using a difference-indifference strategy. For consumption, however, our main focus is on the endline only. This is a response to evidence of systematic measurement error in the baseline consumption data. The summary statistics in Table 3 document the reasons for concern. First, baseline monthly household consumption per capita is implausibly larger than baseline income data. The control group earned an average of 312 rupees per person per month but is measured as having spent 587 rupees; the treatment group earned on average 313 rupees per person per month but is measured as having spent 543 rupees. In contrast, the income and consumption data are within 10 percent of each other in the endline survey. Second, the average monthly per capita consumption expenditure (Rs.587 per person per month, or about US\$1.18 per day in PPP conversion) is implausibly higher in the baseline sample than the rural poverty line (The Tendulkar Committee Report of the Government of India estimates a rural poverty line at Rs. 448 per person per month or about US\$0.90 per day in PPP conversion; Tendulkar, Radhakrishna and Sengupta 2009.) The endline consumption data, however, is consistent with the poverty line for the district: By the time of the endline (2009-10), the local poverty line is 512 rupees, and measured consumption in the treatment group is 496 rupees per person per month. Third, average food expenditures drop by half between the baseline and endline surveys (Table 3), which is not consistent with households reports of improvements in food security as measured by whether any household member skipped meals, whether adults ever go an entire days without eating, or whether all household members had enough food all day, every day (Appendix Table 2). Fourth, the consumption decline is not consistent with rising income as seen in Table 3 (and seen in the region generally). 
For completeness, we present difference-in-difference analyses of the impact of the program on consumption expenditures even though the results may be biased by measurement error. Our focus, though, is on results for consumption using the endline data only. The endlineonly results are consistent with the broader analyses. ${ }^{7}$

The SKS intervention was also assessed in an independent qualitative study conducted 2.5 years after completion of the program (Jawahar and Sengupta 2012). The qualitative study was conducted using seven focus group discussions and 32 individual interviews with program participants and control group households, as well as interviews with program staff. These data are not meant to measure the program's impact, but they provide insight into how the program worked and conditions in treatment and control villages. Overall, the qualitative findings line up with findings from the RCT.

Who were the ultra-poor?

Table 3reports the mean of key indicators in baseline and endline survey waves, by treatment assignment. Households were ineligible for the program if they owned goats, buffaloes or a large flock of chicken, but households could own a few small animals and still be eligible. As a result, about 10 percent of households reported in the baseline survey owning one or more animal(s). Animal ownership differed across treatment status in the baseline survey: seven percent of control households and 13 percent of treatment households owned an animal. The difference is statistically significant.

The average monthly per capita income in the baseline survey, including the value of household-produced consumption items, was slightly above 300 Rupees, equivalent to about

$7 \mathrm{We}$ tried to detect the source of the measurement error, but the source remains unclear. The same survey firm completed all waves of the survey using the same survey instrument but with different survey teams. The survey firm had no role in implementing the intervention itself. 
0.60 US dollars per day in purchasing power parity (PPP) terms. Even though 65 percent of ultra-poor households in the area had more than one source of income, they were very heavily dependent on agricultural labor as a primary source of income: at baseline, more than half of their per capita income came from agriculture labor. Average livestock income was very small, and more than 90 percent of all households did not have income from livestock (not shown). ${ }^{8}$

Participation in government safety nets was heterogeneous in the baseline survey, and remained so throughout the years in which we collected data. On one hand, government programs distributing subsidized foods and basic necessities were used by more than 90 percent of all households. On the other hand, fewer than five percent of households reported in the baseline survey seeking or receiving assets, vocational training or subsidized loans from the government. Participation in the National Rural Employment Guarantee scheme was relatively low at the time of the baseline (34 percent of all households participated), but increased sharply from 2007 to 2010 . By the endline, 80 percent or more of both treatment and control households worked in the scheme.

Even though sample households were among the poorest households in a poor district of India and participation in microfinance excluded them from being eligible for the program, our baseline survey indicates that they had an active, mostly informal, financial life. At baseline, before receiving any service from SKS, more than 50 percent of all households saved and almost three quarters of them had outstanding loans. Average total outstanding loan balances represented eight to 10 times the average per capita monthly income. ${ }^{9}$

\footnotetext{
${ }^{8}$ As indicated above, average per capita monthly consumption appears to be measured with substantial positive error. Table 3 reports the impacts of the program on consumption, which should be taken with caution.

${ }^{9}$ This is notable in the context of the microfinance crisis in Andhra Pradesh: these households did not participate in formal microfinance (other than self-help groups), yet were already over-indebted.
} 
Overall, these baseline descriptive statistics highlight that households eligible for the ultra-poor program and included in our sample were very poor by income measures. They were reliant on income from day labor working for local farmers and on government-subsidized basic goods markets. Despite some animal ownership, these households did not own other productive assets. The population thus fits squarely within the targets set by the ultra-poor program.

\section{Experimental Design and Empirical Strategy}

\section{Design}

The impact assessment of the program is conducted through a randomized controlled experiment, where the level of randomization is the village. The assignment was stratified by village population, number of ultra-poor households as a proportion to total village population, distance from nearest metallic road, and distance from nearest mandal headquarter. ${ }^{10}$

We randomized at the village level due to (i) ease of program implementation and group interventions on the part of SKS, (ii) ease in ensuring that villages were treated according to the initial random assignment (relative to monitoring the treatment of individual households), and (iii) minimization of spillovers from treatment to control households.

The experimental design took into account that the error term may not be independent across individuals. Since treatment status across individuals within a group is identical and outcomes may be correlated, a larger sample size (relative to individual-level randomization) was required to tease out the impact of the program. Power calculations assumed a relatively high level of intra-village correlation $(\rho=0.30)$.

10 A mandal is an administrative unit lower than the district but including several villages. 


\section{Analysis strategy}

Before turning to the analytical strategy, we describe a frame for interpreting the estimated parameters. We focus on the role of substitution between the ultra-poor program and wage labor. The effect can be seen by considering two different interventions, $\mathrm{T}$ and $\mathrm{x}$, that affect income $\mathrm{y}$ such that $y=\beta_{0}+\beta_{1} T+\beta_{2} x+\beta_{3}(T \cdot x)+\varepsilon$ where $E(\varepsilon \mid T, x)=0$. With $x=1$ everywhere, the common measure of impact, which is the treatment-control difference, is thus $\Delta=\mathrm{E}(\mathrm{y} \mid \mathrm{T}=1, \mathrm{x})-\mathrm{E}(\mathrm{y} \mid \mathrm{T}=0, \mathrm{x})=\beta_{1} \mathrm{~T}+\beta_{3}(\mathrm{~T} \cdot \mathrm{x})$. In our context, $\mathrm{T}$ is eligibility for the ultra-poor program and $\mathrm{x}$ is access to the agricultural labor market. In our case, even though access to $\mathrm{T}$ is limited to the treatment group, everyone in the treatment or control group has access to $\mathrm{x}$. Thus the concern is not that the control group is contaminated. Instead, the concern arises from shifts in households' portfolios of economic activities (re-optimization) from $\mathrm{x}$ to $\mathrm{T}$. The two opportunities may interact positively $\left(\beta_{3}>0\right)$ if re-optimization brings out ways that they reinforce each other, or negatively $\left(\beta_{3}<0\right)$ if there is substitution.

With $\mathrm{x}=1$ everywhere, families in treatment areas opt to split their energies between the two available options $\mathrm{T}$ and $\mathrm{x}$, while families in control areas fully participate in their single option $\mathrm{x}$. The treatment-control difference $\Delta=\beta_{1} \mathrm{~T}+\beta_{3}(\mathrm{~T} \cdot \mathrm{x})$ is thus smaller than $\beta_{1} \mathrm{~T}$ when $\beta_{3}<0$. Where there is full displacement, $\beta_{3}$ could be large enough in absolute value to explain the finding that $\Delta=0 .{ }^{11}$ The logic for $\beta_{3}<0$ in our case hinges on the hypothesis that if a person engages in the ultra-poor program, she lacks the time, energy or freedom to simultaneously participate fully in agricultural labor.

11 At the same time, the result could be consistent with there being a potential positive impact when the

alternative intervention is not available $(\mathrm{x}=0$ everywhere $)$ in which case the impact would be $\Delta=\mathrm{E}(\mathrm{y} \mid \mathrm{T}=1, \mathrm{x}=0)-\mathrm{E}(\mathrm{y} \mid \mathrm{T}=0, \mathrm{x}=0)=\beta_{1} \mathrm{~T}$. 
This scenario highlights that families in the treatment group would have been in roughly the same place had the ultra-poor program not existed (assuming they re-optimized and took greater advantage of other labor opportunities). But it is simultaneously true that inputs from the ultra-poor program translated into meaningful outcomes for those it served. The distinction from the finding that $\beta_{1}=0$ (that is, program failure) matters when extrapolating from the result that $\Delta=0$ and for understanding what was actually estimated.

The analytical strategy draws on a series of reduced-form regressions. The difference in the means of the treatment and control groups is the OLS coefficient $\beta$ in the following reducedform regression

$$
Y_{i j}=\alpha+\beta T_{i}+v_{j}+\varepsilon_{i j}
$$

Where $i$ indexes households and $\mathrm{j}$ indexes villages. $\mathrm{Y}$ is the outcome of interest (consumption, income, etc.). $T$ is an indicator variable that equals 1 if household lives in a treatment village and 0 otherwise, and $\beta$ is the impact of the treatment. The variables $v_{j}$ and $\varepsilon_{\mathrm{ij}}$ are the unexplained variance at the village and the household level. In theory, since the treatment was random across villages, $\varepsilon_{\mathrm{ij}}$ is uncorrelated with T. The coefficient of interest $\beta$ is the intent-to-treat estimate which measures the expected change in the outcome for a household that was offered the treatment. This is different from the impact of actually participating in the program ("treatment on the treated" estimates) because of partial compliance. That is, not every household that was offered the treatment participated in the program; as detailed above, almost 30 percent of households invited to participate declined the offer. The treatment on the treated estimate is the parameter of interest when we want to capture the cost-effectiveness of the program, but it is biased by the self-selection of households into actually participating in the program or not. The 
intent-to-treat estimate indicates the causal impact of being assigned to participate in the program, and it is the focus of our analysis.

The intent-to-treat analysis is complemented by treatment-on-the-treated estimates obtained by estimating the impact of the program with an instrumental variable specification, instrumenting actual participation in the program with the random assignment. Table 2 reports these results for select outcomes. The signs and statistical significance of the coefficients are similar to those of coefficients obtained by regressing each outcome on the treatment indicator following specification (2) below (our main results, displayed in Table 6 through Table 11). Coefficients obtained by an instrumental variable specification, however, tend to be of a larger magnitude, confirming that the program had a strong effect on households which participated than the intent-to-treat measures indicate.

While randomizing participants into the treatment and control groups produces similar groups in expectation, this outcome is not guaranteed in practice and was not achieved in our evaluation. The unit of randomization was the village, and household-level data show some statistically significant differences between households in treatment and control villages. We therefore adapt our regression specification to include variables controlling for the characteristics according to which treatment and control households differ at baseline, and to exploit the panel nature of our data:

$$
Y_{i j}=\alpha+\beta\left(T_{i j} * P_{i t}\right)+\delta P_{i t}+\gamma X_{i j}+v_{j}+\varepsilon_{i j t}
$$

Where the subscript $t$ indexes the waves of data (baseline, endline), $\mathrm{P}_{\text {it }}$ is a binary variable equal to Oif the data come from the baseline surveys and 1 if the data come from the endline survey, $\mathrm{X}_{\mathrm{ij}}$ includes the baseline values of five control variables described in the next paragraph, and all other quantities are as in equation (1).We focus our analysis on long-term impacts, measured 
with baseline and endline waves. Typical impact evaluations focus on coefficient $\beta$, which shows the impact of the program above and beyond changes that happened to the control group (indicated by $\delta$ ). In this analysis, for most outcomes of the program, $\beta$ does not reach conventional levels of statistical significance but many $\delta$ coefficients are large and statistically significant, showing that, on average, both treatment and control households in the study area experienced important changes in their economic situation.

The specification in (2) also allows the assessment of interactions with other markets and interventions. To get at possibilities for substitution, we define $\mathrm{Y}$ as participation in competing programs or as income from alternative sources. We then quantify how the availability of the ultra-poor program affected other economic activities such as participation in the agricultural labor market.

Appendix Table 3 shows the average baseline values of characteristics of the treatment and control groups. At baseline, treatment and control households were similar on most demographic, consumption, income, health, occupation and housing characteristics. But despite the random assignment of villages into treatment and control groups, households living in treatment villages appear better off than control households along some dimensions. In Appendix Table 3 we consider 38 key variables, and find five dimensions for which treatment and control households differ significantly at baseline. These include the percentage of households that report holding some form of savings (51 percent of control households and nearly 60 percent of treatment households), participate in the NREG employment scheme (31 percent of control group households and 37.5 percent of treatment households), have outstanding loans (69 percent of control households against 74 percent of treatment households), have outstanding loans from self-help groups (47 percent of control households but 58 percent of treatment households), and 
own any animal (seven percent control households, versus 13 percent of treatment household own one or more heads of livestock or poultry). We control for the baseline value of these five characteristics in all analyses.

\section{Results}

This section describes impacts on the core outcomes in Table 6 through Table 11. The impact of the program on additional outcomes is reported in Appendix Tables.

\section{Asset accumulation}

The ultra-poor program was designed to help households accumulate assets in at least two ways. First, the program had a direct impact on agricultural or enterprise asset ownership by transferring an animal or by providing working capital for a non-farm microenterprise. Second, the program helped indirectly by improving financial tools and income.

We find a relative increase in animal ownership among treatment households, but no impact of the program on the ownership of other assets. The first four columns of Table 5 analyze the impact of the program on the ownership of assets such as housing, land, livestock, and household and agricultural assets. The assets index is the principal components index of household durable goods owned by the household (such as television, table, or jewelry). The agricultural assets index is the principal components index of household agricultural durable goods (such as plough, tractor, or pump) and animals owned by the household. Ownership of household and agricultural assets did not significantly change between baseline and endline surveys, neither for control nor for treatment households. The finding of no impacts on ownership of assets is corroborated by qualitative insights suggesting that households were 
largely unable to diversify their asset base, even when asset holdings increased (Jawahar and Sengupta 2012).

The lack of impacts on asset ownership could be a sign that the program failed to even transfer a productive asset to participating households. Patterns of animal ownership, however, reflect the implementation of the program and confirm that this was not the case. Table 3 shows that the percentage of households reporting owning an animal increased between baseline and endline surveys for treatment households, but not for control households. Column 5 of Table 5 provides regression estimates of these changes: being assigned to participate in the program led to a 24-percentage point increase in the likelihood to own livestock, which includes animals such as buffaloes and goats that were provided by the program. As a check, we note that ownership of poultry did not increase, which is consistent with the fact that chicken and ducks were not available as grants from the program.

\section{Animal ownership}

Increasing animal ownership was a primary means for the program to support ultra-poor households. We should therefore see a clear impact of the program on the likelihood of owning animals in the endline survey. Instead, we see substantial drop out. While the coefficient showing the impact of the program on livestock ownership is statistically significant, the magnitude of the increase in the rate of livestock ownership is relatively low for a program based on the premise that animal rearing is economically profitable and generally desirable for ultrapoor households in the area. ${ }^{12}$ Of the 405 households who actually participated in the program (576 lived in a village assigned to the treatment group), nearly 90 percent chose animals as the

12 We note that there is no indication that households joined the program with the intent of eventually selling the asset. 
asset they wish to receive from the program. In the endline, only 43 percent of the 362 households who chose livestock as their program asset still owned any animal. Consistent with the existence of dropout bias, the data suggest that some households in the treatment group sold the animal they received from the program (once the program implementation period ended and SKS stopped monitoring participants), used the revenue to pay off debt, and returned to wage labor.

Table 4 describes characteristics of treatment households based on their animal ownership at endline. At baseline, households that will later keep the animal given by the program were overall similar to those who eventually sell their animal, with the exception of the amount of land owned, which was larger for those who will own an animal at endline.

Panel B of Table 4 shows that households who did not own any animal at endline were more likely to report having sold animals in the last 12 months, as well as to report higher income from selling animals than those who still owned animals. The evidence suggests underreporting of livestock sales, however. Table 4, Panel B, indicates that fewer than 20 percent of households who participated in the program and did not own animals in the endline reported having sold their animal. To pursue the possibility that this is under-reported, we worked with SKS to implement a follow-up survey of treatment households which chose buffalos or goats as their activity in the program but reported not owning an animal at the endline survey. In this follow-up survey, two-thirds of the valid responses indicate that the animal was sold, and eight percent indicated still owning and caring for the animal (the remaining households either lost their animals to illness or were leasing them out.)

Data on household indebtedness reinforce the argument that households that did not hold on to their animal actually sold it. Panel B of Table 4 indicates that, compared to households that 
held on to their animal, households that did not own animals in the endline wave were 19 percentage points less likely to have outstanding loans, reduced their number of loans outstanding, and had significantly lower average outstanding loan amounts.

This suggests that, given the lack of net positive impact of the program, some households may have made a choice to stop pursuing their livestock-related activity and used the proceeds from selling their animal(s) for other purposes. At the same time, households that held onto their animals did better than others by the endline. Total per capita income and expenditures increased more for households that held on to their animals than for those who chose to sell them. The difference is statistically significant (not shown). We cannot causally interpret these differences since holding on to animals is an endogenous choice, but the pattern is consistent with heterogeneity in treatment effects, followed by re-optimization toward wage labor by those who experienced weaker impacts from program participation.

\section{Income and its composition}

One of the basic changes that we observe is in the income of ultra-poor households. The average monthly per capita total income increased from Rs.312 (US\$18.9 in PPP conversion) in the baseline to Rs.518 (US\$31.3 in PPP conversion) in the endline, a 66 percent increase. Figure 1 shows that the distribution of monthly income per capita shifted to the right and flattened between the baseline and endline surveys. It also highlights that these changes happened in a similar fashion for treatment and control households.

This main finding holds when controlling for unbalanced characteristics of the households at baseline and village fixed effects. Table 6 reports the coefficients from a panel regression using the specification detailed in equation (2) above and the log of per capita monthly income. On average, both treatment and control households experienced a large and 
statistically significant increase in total income per capita. Over the 3 years between baseline and endline surveys, average household income per capita increased by 62 percent for households in the treatment group (Panel B) and 74 percent for households in the control group (Panel A).

The ultra-poor program itself, however, failed to raise households' total income per capita beyond income increases for households in the control group. Panel $\mathrm{C}$ analyzes the households in a cross-section at the endline. There, the average household in treatment villages had an income almost identical to that of the average household in control villages. This lack of net average impact does not mean that the program failed to create any impact. Figure 2 provides a visual summary of our argument. While the levels of and change in total income were not statistically different in treatment and control groups, the change in the composition of income was. Treatment households obtained a larger share of their income from livestock than control households, while the latter obtained a larger share of their income from agriculture labor than the former.

We document with more precision the interaction of the ultra-poor program with other opportunities by defining the variable on the left-hand side of equation (2) as various components of household income. ${ }^{13}$ Columns 3 and 6 of Table 6 confirm that the program was successful in raising income from livestock, but simultaneously caused a stagnation of agricultural labor income. In the long run, treatment households experienced a 97 percent increase in livestock income, as well as a nine percent decrease in income from agricultural labor (the coefficient is not statistically significantly different from zero). ${ }^{14}$ The change in income from treatment households' re-optimizing away from agriculture labor to livestock rearing is most

\footnotetext{
${ }^{13}$ We also tested a seemingly unrelated regression specification to analyze the different sources of income. Results are qualitatively similar and are not reported here.

${ }^{14}$ We attribute the large change in other income for all households, reported in column 8 , to measurement errors rather than an economically meaningful phenomenon.
} 
visible in Panel C of Table 6: at endline, on average, the income from livestock of households in treatment village was 111 percent higher than that of households in control village, and the former's income from agriculture labor was 35 percentage points lower than the latter's.

Changes in the household's use of time corroborate the observed changes in income. Measures of time use presented in Table 7 include both adults and children to take into account the fact that the latter often help with tending animals and with household chores. The tableshows that aggregate measures of time spent in productive activities, in leisure, and doing chores did not change differently for treatment and control households. Detailed measures of time use over the past 24 hours, however, show that treatment households spent more time tending animals than control households, and less time doing agriculture labor. On average, between baseline and endline surveys, households participating in the program reduced the time they spent doing agricultural labor by 15 minutes while control households increased the time they devote to this activity by 44 minutes, leading to a net difference of 59 minutes per day.

\section{Consumption}

As described above, measures of food consumption likely suffer from measurement error. We describe the impact of the program on household consumption nonetheless since it is an important outcome. Figure 1 shows the density of total monthly per capita consumption for treatment and control households, and Figure 3 details consumption into food and non-food consumption. As the graphs indicate, the distribution of total and food expenditures shifted towards the left side, indicating a decrease over time consistent with substantial measurement error in the baseline. The decrease in total and food expenditures did not affect treatment and control households differently, but medical expenditures decreased significantly more for treatment households, making a marginal impact on non-food expenditures. 
In Table 8 we report the results from estimating equation (2), with various measure of monthly per capita expenditures as dependent variables. The regression results corroborate that average total expenditures decreased between baseline and endline survey for all households, driven by measurement error causing a large decrease in food expenditures. The difference between the treatment and control households, however, was not statistically significant.

To limit the influence of measurement error, Panel $\mathrm{C}$ of Table 8 presents coefficients from a cross-sectional regression on endline data only. The coefficients on the binary variable indicating assignment to the ultra-poor program are all small and not statistically significant, showing the lack of average impact of the program on per-capita household expenditures.

Unlike other measures of expenditures, the data in Panel A of Table 8 suggest that medical expenditures declined sharply due to the program. This might in fact be a good sign. Assuming that treatment households were not more likely to feel in better health, to be too sick to work, nor to have consulted a doctor or gone to a hospital in the last year (Appendix Table 4), we cautiously interpret the decrease in medical expenditures as positive outcome consistent with the program's training of a local basic health responder in the village responsible for the basic diagnoses, referrals, and the provision of common medicines. The result, however, disappears in Panel $\mathrm{C}$ which relies on the endline cross-section only.

\section{Saving and Borrowing}

An important motivation for the program was to help ultra-poor households establish a microenterprise with a regular income flow that would help them later "graduate" into microfinance or other sustained source of support. In this section, we explore the impact of the program on the financial lives of the poor households. 
Table 9 reports that the program had a strong impact on savings in the short run, as it required treatment households to save every week such that at the end of 18 months they had accumulated at least Rs. 800 to "graduate." As a result, immediately at the end of the program treatment households reported being more likely to save than control households, and reported savings balances 1.3 times that of control households, on average (data not shown).

These effects did not persist in the long run, however. On average, in the long run all households reduced their borrowing and were more likely to save than they were in the baseline, but not differently so for treatment and control households. Qualitative insights confirmed that, two and a half years after the program ended, almost all participants had withdrawn their savings and closed the post office account that had been opened for them during the program (Jawahar and Sengupta 2012). Some households prefer to keep cash at home, but the lump sum created while in program was commonly used to repay outstanding debts.

The debt reduction is visible is our quantitative data for both treatment and control households, measured as (i) the likelihood to have outstanding loans, (ii) the number of outstanding loans, and (iii) the total amount of loans outstanding. The drop in debt among treatment households that sold their animal between midline and endline surveys is not large enough to be reflected in the overall treatment-versus-control comparison.

Appendix Table 5 looks at the impact of the program on access to credit. It shows that, over the long run, sources of loans were not significantly different for treatment households than for control households. The program also did not significantly increase poor households' use of formal credit.

Households strongly reduced their use of moneylender loans - treatment households significantly more so than control households. The percentage of control households which had 
outstanding loans from moneylenders fell by 10 percentage points between the baseline and endline surveys, a large effect which represents about 20 percent of the baseline percentage of all households' borrowing from moneylenders. Treatment households were an additional 15 percentage points less likely to borrow from moneylenders, for a total effect representing onethird of the baseline percentage of households borrowing from moneylenders.

\section{Use of government safety nets}

The expected net impact of the ultra-poor program on the use of government safety nets is ambiguous. On one hand, part of the training provided to ultra-poor households was meant to empower them to connect with existing support in their community, including government social services. On the other hand, a long term goal was to create independent livelihoods and reduce reliance on public safety nets.

Table 10 shows no direct evidence of a substitution of the ultra-poor program with specific government safety net programs. While participation in most safety net schemes increased for all households between the baseline and endline surveys, ultra-poor households were not statistically significantly more or less likely to participate in any of them relative to control households. In the qualitative study, Jawahar and Sengupta (2012) make a similar note that "political competition" led to an increased awareness of, and participation in, government safety nets for all households in Andhra Pradesh. For this outcome, as for other outcomes of the ultra-poor program, context mattered greatly.

The National Rural Employment Guarantee scheme is of particular interest. The NREG scheme is the largest public safety net scheme in the world. In its fiscal year 2010-2011, it provided employment to 53 million households in India, including six million in Andhra Pradesh (Ministry of Rural Development of the Government of India 2011). As noted in the introduction, 
the NREG scheme provides up to 100 days of unskilled wage employment per household, for a daily wage that averaged Rs. 115 in March 2011. Although a minority of households actually worked for 100 days in fiscal year 2010-2011, the potential income from NREG represents a substantial proportion of an ultra-poor's total yearly income and could contribute to dampening the measured impact of the ultra-poor program. Our data, however, do not support this hypothesis. Even though participation in NREG increased sharply in our sample between the baseline and endline surveys (from about 34 percent to about 81 percent), the rate of increase was not statistically significantly different for treatment and control households (Table 10, column 1) and the amount earned from working in the scheme was similar for treatment and control households in the endline survey (Table 3). ${ }^{15}$

\section{Heterogeneity in impacts}

To assess heterogeneous impacts of the program, we divided the sample into subsamples of households based on land ownership, house ownership and livestock ownership at baseline. Table 11 shows the impact of the program on total monthly per capita income for each of these subgroups.

The results suggest that poorer households, as characterized by not owning livestock, land or a house prior to the program, tended to do worse in the program. Poorer households witnessed a larger decline in average income by the end of the study relative to their counterparts who owned assets at the start. While the statistical significance of these differences does not provide a compelling argument on its own, Jawahar and Sengupta's (2012) qualitative study also

15 The lack of displacement of NREG participation arises in part because the work is close to the village (and sometimes within it), making it possible to simultaneously care for livestock. Working as an agricultural laborer, in contrast, usually requires travel and being away from home for extended stints. 
concludes that the impact of the program depended to a significant extent on the amount of experience with the livelihood activity chosen and the availability of support networks.

\section{Conclusion}

We report on an innovative asset transfer program aimed at ultra-poor households in rural India. The program aims to permanently shift ultra-poor households' living conditions by providing resources (including training, an asset, and other support) intensively but for a limited time, rather than simply providing an ongoing safety net. The basic idea of the program is for households to establish a microenterprise with a regular cash flow such that they can move out of extreme poverty. Over the 18 months of the program, households received support in the form of intensive training and monitoring, and a stipend to meet enterprise-related expenses (but not to support household consumption).

The results are surprising: we find no significant long term net impacts of the program on income and asset accumulation of ultra-poor households. (Nor do we find impacts on total consumption in analysis of the endline survey, a preferred analysis given evidence of substantial measurement error in the baseline consumption data.)

We argue that the results are explained in large part by substitution with other economic activities. This is manifested as both substitution bias and dropout bias (Heckman et al. 2000). During the study period, wages in agricultural labor were rising steadily in the region, so that households in the control group were able to improve their economic conditions in parallel with households in the treatment group. It is left open whether the composition of support could have made a difference for households - especially the very poorest- which struggled to maintain their microenterprises, or whether there might have been greater impacts had the implementing organization maintained a presence in the villages after the program ended. 
Taken as a whole, the study shows that the program helped households create new livelihoods as intended. At the same time, the study highlights the need to interpret evaluations in the context of the economic opportunities faced by families and their ability to re-optimize their livelihood strategies. Because of the substitution of economic activities, even a relatively well-implemented intervention delivered resources as intended but yielded no net average impact. In another economic setting, however, the exact same intervention targeted to an identical population might have generated very different levels of net impact.

\section{Acknowledgments}

We thank Swayam Krishi Sangam (SKS), especially Vikram Akula, R. Divakar, M. Rajesh Kumar and the staff in Narayankhed for their collaboration and support. We thank the Ford Foundation for funding. We received helpful comments from Dean Karlan, Alexia Latortue, Aude de Montesquiou, Syed Hashemi, and Ravi Jagannathan. We also thank seminar participants at NYU, the Indian School of Business, Nagoya University, the University of Tokyo, and GRIPS-Tokyo, and conference participants at CGAP (Paris), NEUDC, and the Indian Statistical Institute. Ashwin Ravikumar, Kanika Chawla, Naveen Sunder, Shilpa Rao, Ruchika Mohanty, Monika Engler and Surenderrao Komera provided excellent research assistance. Jonathan Morduch thanks the Gates Foundation for support from the Financial Access Initiative at NYU. He also thanks the Center for Economic Institutions in the Institute for Economic Research of Hitotsubashi University for hospitality in 2011-12. 


\section{References}

Alcott, Hunt and Sendhil Mullainathan 2012. "External Validity and Program Selection Bias." NBER Working paper 18373, September.

Bandiera, Oriana, R. Burgess, N. Das, S. Gulesci, I. Rasul, R. Shams, and M. Sulaiman. 2012. "Asset Transfer Programme for the Ultra Poor: A Randomized Control Trial Evaluation." BRAC Research and Evaluation Division CFPR Working Paper No. 22, December.

Banerjee, Abhijit, Esther Duflo, Raghabendra Chattopadhyay, and Jeremy Shapiro. 2007. "Targeting Efficiency: How well can we identify the poor?," IFMR Working Paper No. 21.

Banerjee, Abhijit, Esther Duflo, Raghabendra Chattopadhyay, and Jeremy Shapiro. 2011."Targeting the Hard-Core Poor: An Impact Assessment," MIT, Department of Economics.

Bardhan, Prandab and Christopher Udry. 1999. Development Microeconomics. New York: Oxford University Press.

Bowles, Samuel, Steven Durlauf, and Karla Hoff, ed. 2006. Poverty Traps. Princeton, NJ: Princeton University Press.

Das, Jishnu, Stefan Dercon, James Habyarimana, Pramila Krishnan, Karthik Muralidharan, and Venkatesh Sundararaman. 2013. "School Inputs, Household Substitution, and Test Scores." American Economic Journal: Applied Economics, 5(2): 29-57.

Deaton, Angus. 1997. The Analysis of Household Surveys. Baltimore, MD: World Bank/Johns Hopkins University Press.

Deaton, Angus. 2010. "Instruments, Randomization, and Learning about Development.” Journal of Economic Literature 48 (June 2010): 424-455.

Drèze, Jean, and Reetika Khera, “The BPL Census and a Possible Alternative," Economic and Political Weekly, 45(2010), February 27, 2010. Special Article.

Duflo, Esther, Rachel Glennerster, and Michael Kremer. 2008. "Using Randomization in Development Economics Research: A Toolkit." In T. Paul Schultz, and John Strauss (eds.) Handbook of Development Economics, Volume 4. North Holland: Elsevier, pp. 3895-62.

Eldridge, Sandra, Deborah Ashby, Catherine Bennett, Melanie Wakelin, and Gene Feder. 2008. "Internal and External Validity of Cluster Randomized Trials: Systematic Review of Recent Trials.” British Medical Journal 336:876, April 172008.

Emran, M. Shahe, Virginia Robano, and Stephen Smith. 2009. "Assessing the Frontiers of UltraPoverty Reduction: Evidence from CFPR/TUP, an Innovative program in Bangladesh," George Washington University, Department of Economics.

Heckman, James and Edward Vytlacil. 2007. "Econometric Evaluation of Social Programs, Part II: Using the Marginal Treatment Effect to Organize Alternative Econometric Estimators to Evaluate Social Programs, and to Forecast their Effects in New Environments." In James Heckman and Edward Leamer, eds., Handbook of Econometrics, volume 6B. Amsterdam: Elsevier, pp. 4875-5144. 
Heckman, James, Neil Hohmann, Jeffrey Smith and Michael Khoo. 2000. "Substitution and Dropout Bias in Social Experiments: A Study of an Influential Social Experiment." Quarterly Journal of Economics 115 (2), May: 651-694.

Imbert, Clément and John Papp. 2012. "Equilibrium Distributional Impacts of Government Employment Programs: Evidence from India's Employment Guarantee.” Paris School of Economics Working Paper No. 2012 - 14.

Jalan, Jyotsna, and Rinku Murgai. 2006."An Effective "Targeting Shortcut"? An Assessment of the 2002 Below-Poverty Line Census Method," available at http://www.cdedse.org/conf2007/rmurgai.pdf.

Jawahar, Vinay, and Anasuya Sengupta. 2012. "SKS Ultra Poor Program: Qualitative Evaluation of Sustainability of Program Outcomes," BRAC Development Institute.

Krishna, Anirudh, Meri Poghosyan, and Narayan Das. 2012. "How Much Can Asset Transfers Help the Poorest? Evaluating the Results of BRAC's Ultra-Poor Programme (20022008)," Journal of Development Studies, 48: 254-267.

Mallick, Debdulal. 2009. "How Effective is a Big Push for the Small? Evidence from aQuasi Random Experiment," available athttp://mpra.ub.uni-muenchen.de/22824.

Matin, Imran, and David Hulme. 2003. "Program for the Poorest: Learning from the IGVGD Program in Bangladesh," World Development, 31: 647-665.

Ministry of Rural Development of the Government of India.2011. "The Mahatma Gandhi National Rural Employment Guarantee Act 2005," available athttp://nrega.nic.in/netnrega/MISreport.aspx?fin_year=2010-2011.

Ministry of Statistics and Programme Implementation of the Government of India. 2005. "National Sample Survey Office Report 2004-2005," available at http://mospi.nic.in/Mospi_New/site/inner.aspx?status=3\&menu_id=31.

Morduch, Jonathan. 1999. “The Microfinance Promise," Journal of Economic Literature, 37 : 1569-1614.

Sachs, Jeffrey. 2005.The End of Poverty: Economic Possibilities for Our Time. New York: Penguin.

Swayam Krishi Sangam (SKS). 2011. Annual Report: 2010-11. Hyderabad, India: SKS.

Tendulkar, Suresh, R. Radhakrishna, and Suranjan Sengupta. 2009.Report of the expert group to review the methodology for estimation of poverty. New Delhi: Govt of India Planning Commission. 
Table 1. Average Costs of the Program

\begin{tabular}{lcc}
\hline & Cost in Rupees & Cost in US Dollars \\
\hline Livelihoods asset & 7,000 & 140 \\
Capacity building & 5,350 & 107 \\
Implementation costs & 4,700 & 94 \\
Targeting costs & 260 & 5 \\
Stipend (working capital allowance) & 550 & 11 \\
\hline Total cost per program participant & 17,860 & 357 \\
\hline Notes: SKS NGO calculations, 2009. 50 Indian rupees = US\$1.
\end{tabular}


Table 2. Impact of the Ultra-Poor Program, Instrumental Variable Specification

\begin{tabular}{|c|c|c|c|c|c|c|c|c|}
\hline & \multicolumn{3}{|c|}{ Income } & \multirow{2}{*}{$\begin{array}{l}\text { Time in } \\
\text { agr. labor }\end{array}$} & \multirow{2}{*}{$\begin{array}{c}\text { Time } \\
\text { tending } \\
\text { animals }\end{array}$} & \multirow{2}{*}{$\begin{array}{l}\text { Total } \\
\text { expend. }\end{array}$} & \multirow{2}{*}{$\begin{array}{l}\text { HH has } \\
\text { loans? }\end{array}$} & \multirow{2}{*}{$\begin{array}{c}\mathrm{HH} \\
\text { saves? }\end{array}$} \\
\hline & total & agr. labor & livestock & & & & & \\
\hline \multirow[t]{2}{*}{ Post*Treatment } & -0.19 & $-0.50^{*}$ & $1.44 * * *$ & $-80 * *$ & $18 * * *$ & -0.07 & -0.04 & -0.05 \\
\hline & $(0.13)$ & $(0.26)$ & $(0.23)$ & $(34)$ & $(5)$ & $(0.08)$ & $(0.08)$ & $(0.07)$ \\
\hline \multirow{2}{*}{$\begin{array}{l}\text { Post ( } 0 \text { if baseline, } 1 \text { if } \\
\text { endline })\end{array}$} & $0.74 * * *$ & 0.21 & -0.04 & $50 * * *$ & $-4 * *$ & $-0.21 * * *$ & $-0.22 * * *$ & $0.09 * *$ \\
\hline & $(0.07)$ & $(0.15)$ & $(0.03)$ & (17) & (2) & $(0.04)$ & $(0.04)$ & $(0.04)$ \\
\hline Observations & 1,976 & 1,991 & 1,909 & 1,973 & 1,992 & 2,000 & 2,000 & 2,000 \\
\hline R-squared & 0.150 & 0.020 & 0.158 & 0.009 & 0.013 & 0.041 & 0.154 & 0.323 \\
\hline $\begin{array}{l}\text { Mean of dep. var. at } \\
\text { baseline }\end{array}$ & 318 & 178 & 3.6 & 264 & 3.6 & 568 & .714 & .557 \\
\hline \multicolumn{9}{|c|}{$\begin{array}{l}\text { Notes: } * * * \mathrm{p}<0.01, * * \mathrm{p}<0.05, * \mathrm{p}<0.1 \text {. Regressions in this table report coefficients from an instrumental variable specification, where actual } \\
\text { participation in the program is instrumented by the random assignment to participate. All regressions include village-level fixed effects. } \\
\text { Standard errors are clustered at the village level. Variables controlling for unbalanced characteristics of the sample (baseline values of whether } \\
\text { the household saves, participates in EGS, receives a pension, has outstanding loan(s) from self-help groups, and own an animal) are included in } \\
\text { the regressions but not shown. Income and consumption measures are the log of monthly per capita income or consumption (log of } 1+\text { amount } \\
\text { in } 2007 \text { Rupees; } 1 \text { USD } \approx 40 \mathrm{Rs).} \mathrm{Time} \mathrm{in} \mathrm{agricultural} \mathrm{labor} \mathrm{and} \mathrm{tending} \mathrm{animal} \mathrm{are} \mathrm{measured} \mathrm{in} \mathrm{minutes} \mathrm{in} \mathrm{the} \mathrm{last} 24 \text { hours. The means of the } \\
\text { dependent variables at baseline are in level form. Livestock income includes income from irregular sales of animals. }\end{array}$} \\
\hline
\end{tabular}


Table 3. Summary Statistics for Control and Treatment Households

\begin{tabular}{lcccccc}
\hline & \multicolumn{2}{c}{ Baseline } & \multicolumn{2}{c}{ Endline } & \multicolumn{3}{c}{ Percent change } \\
baseline-endline \\
& $\mathrm{C}$ & $\mathrm{T}$ & $\mathrm{C}$ & $\mathrm{T}$ & $\mathrm{C}$ & $\mathrm{T}$ \\
\hline Total income & 312 & 313 & 520 & 516 & 67 & 65 \\
Income from livestock & 2.4 & 3.6 & 7.6 & 62.0 & 221 & 1,644 \\
Income from agriculture labor & 174 & 176 & 316 & 267 & 82 & 51 \\
Income from non-agriculture labor & 60 & 56 & 105 & 103 & 75 & 85 \\
Total expenditures & 587 & 543 & 496 & 471 & -15 & -13 \\
Food expenditures & 277 & 278 & 142 & 139 & -49 & -50 \\
Non-food expenditures & 310 & 265 & 355 & 333 & 15 & 25 \\
Household has savings (percent) & 51 & 59 & 60 & 65 & 18 & 9 \\
Per capita savings balance & 110 & 140 & 292 & 295 & 165 & 111 \\
Household saves in SHG (percent) & 47 & 58 & 58 & 55 & 22 & -4 \\
Household has outstanding loan (percent) & 68 & 74 & 47 & 49 & -32 & -34 \\
Per capita outstanding loan balance & 2,479 & 3,041 & 1,447 & 1,531 & -42 & -50 \\
Household borrows from moneylender (percent) & 28 & 31 & 8 & 9 & -72 & -71 \\
Household borrows from SHG (percent) & 30 & 40 & 30 & 33 & 1 & -16 \\
Household sought/received government assets & 3.3 & 4.3 & 9.9 & 9.3 & 203 & 115 \\
(percent) & & & & & & \\
Household sought/received government training & 0 & 1 & 8 & 6 & 1,761 & 1,141 \\
(percent) & & & & & \\
Household received goods from PDS (percent) & 93 & 93 & 98 & 98 & 5 & 6 \\
Household received BPL rationing (percent) & 91 & 93 & 96 & 98 & 5 & 6 \\
Household sought/received NREG work (percent) & 31 & 37 & 82 & 80 & 167 & 116 \\
Number of days household worked in NREG & $\mathrm{n} / \mathrm{a}$ & $\mathrm{n} / \mathrm{a}$ & 32 & 35 & $\mathrm{n} / \mathrm{a}$ & $\mathrm{n} / \mathrm{a}$ \\
Monthly per capita income from NREG & $\mathrm{n} / \mathrm{a}$ & $\mathrm{n} / \mathrm{a}$ & 72 & 76 & $\mathrm{n} / \mathrm{a}$ & $\mathrm{n} / \mathrm{a}$ \\
Household owns any animal(s) (percent) & 7 & 13 & 6 & 32 & -22 & 149 \\
\hline
\end{tabular}

Notes: All data are averages, except in the last two columns. All amounts are in Rupees of 2007. The percentage change displayed in the last two columns may be different from the percentage change calculated from data displayed in the table because of rounding. " $\mathrm{C}$ " indicates control households. "T" indicates treatment households. Income and expenditures are monthly per capita values. Savings in and borrowing from specific institutions is not conditional on the household having savings/borrowings. PDS and BPL rationing are government schemes providing basic goods at a subsidized price to poor households. The number of days worked in NREG and income from NREG are conditional on participating in the NREG scheme. 
Table 4. Characteristics of Treatment Households, by Animal Ownership Status in Endline Survey

\begin{tabular}{lccc}
\hline & $\begin{array}{c}\text { Did not own } \\
\text { animal in endline }\end{array}$ & $\begin{array}{c}\text { Owned animal(s) } \\
\text { in endline }\end{array}$ & p-value \\
\hline Pousehold size & 3.2 & 3.6 & 0.008 \\
Average age of household members & 30.4 & 29.6 & 0.512 \\
Acres of land owned & 0.38 & 0.56 & 0.042 \\
Total monthly income per capita (Rs) & 331 & 297 & 0.273 \\
Owned any animal (percent) & 12 & 16 & 0.267 \\
\hline & $\quad$ Panel B. Endline characteristics & & \\
Household sold animal in last 12 months (percent) & 1 & 16 & $<0.001$ \\
Monthly income from sales of animals (Rs) & 4 & 35 & $<0.001$ \\
Total monthly income per capita (Rs) & 489 & 576 & 0.007 \\
Monthly agriculture labor income per capita (Rs) & 273 & 253 & 0.342 \\
Monthly livestock income per capita (Rs) & 20 & 160 & $<0.001$ \\
Household had unexpected event in last year (percent) & 7 & 18 & $<0.001$ \\
If event: total cost of event(s) (Rs) & 30,417 & 41,099 & 0.449 \\
Household has any loan outstanding (percent) & 42 & 61 & $<0.001$ \\
Number of loans outstanding & 0.48 & 0.79 & $<0.001$ \\
Amount of loans outstanding (Rs) & 2,800 & 5,473 & $<0.001$ \\
\hline Notes: Sample is constituted of treatment households only. Data are averages. The p-values are from t-tests of the difference between the means. \\
All amounts are in Rupees of 2007.
\end{tabular}


Table 5. Impact of the Ultra-Poor Program on Asset Ownership

\begin{tabular}{lccccccc}
\hline & $\begin{array}{c}\text { Household } \\
\text { owns its } \\
\text { house? }\end{array}$ & $\begin{array}{c}\text { Acres of } \\
\text { land owned }\end{array}$ & $\begin{array}{c}\text { Assets } \\
\text { index }\end{array}$ & $\begin{array}{c}\text { Agr. assets } \\
\text { index }\end{array}$ & $\begin{array}{c}\text { Household } \\
\text { owns } \\
\text { livestock? }\end{array}$ & $\begin{array}{c}\text { Household } \\
\text { owns } \\
\text { poultry? }\end{array}$ & $\begin{array}{c}\text { Household } \\
\text { owns } \\
\text { plough? }\end{array}$ \\
\hline Post*Treatment & -0.003 & $-0.172 *$ & -0.059 & 0.210 & $0.242 * * *$ & -0.002 & -0.007 \\
& $(0.032)$ & $(0.101)$ & $(0.125)$ & $(0.134)$ & $(0.040)$ & $(0.018)$ & $(0.009)$ \\
Post (0 if baseline, 1 if & $0.139^{* * *}$ & 0.108 & 0.028 & -0.131 & -0.015 & -0.015 & -0.002 \\
endline) & $(0.023)$ & $(0.090)$ & $(0.086)$ & $(0.089)$ & $(0.014)$ & $(0.010)$ & $(0.007)$ \\
& $0.653^{* * *}$ & $0.388^{* * *}$ & $-0.372^{* * *}$ & $-0.112^{* *}$ & $0.037 * *$ & $0.028^{* * *}$ & $0.009 * *$ \\
Constant & $(0.026)$ & $(0.044)$ & $(0.078)$ & $(0.049)$ & $(0.014)$ & $(0.008)$ & $(0.004)$ \\
Observations & 1,995 & 1,956 & 1,989 & 1,977 & 1,992 & 1,978 & 1,994 \\
R-squared & 0.040 & 0.015 & 0.053 & 0.145 & 0.179 & 0.142 & 0.040 \\
$\begin{array}{l}\text { Mean of dep. var. at } \\
\text { baseline }\end{array}$ & 0.711 & 0.414 & -0.007 & 0.016 & 0.069 & 0.050 & 0.013 \\
\hline
\end{tabular}

Notes: $* * * \mathrm{p}<0.01, * * \mathrm{p}<0.05, * \mathrm{p}<0.1$. All regressions include village-level fixed effects. Standard errors are clustered at the village level. Regressions in which the dependent variable is a binary variable are run as linear probability models. Variables controlling for unbalanced characteristics of the sample (baseline values of whether the household saves, participates in EGS, receives a pension, has outstanding loan(s) from self-help groups, and own an animal) are included in the regressions but not shown. The assets index is the principal components index of household durable goods owned by the household (e.g. television, table, jewelry). The agricultural assets index is the principal components index of household agricultural durable goods and animals owned by the household (e.g. plough, tractor, pump, livestock). 
Table 6. Impact of the Ultra-Poor Program on Income

\begin{tabular}{|c|c|c|c|c|c|c|c|c|}
\hline & Total & $\begin{array}{l}\text { Ag. self- } \\
\text { empl. }\end{array}$ & $\begin{array}{l}\text { Ag. } \\
\text { labor }\end{array}$ & $\begin{array}{c}\text { Non-ag. } \\
\text { labor }\end{array}$ & $\begin{array}{l}\text { Salaried } \\
\text { empl. }\end{array}$ & $\begin{array}{l}\text { Live- } \\
\text { stock }\end{array}$ & $\begin{array}{l}\text { Non-ag. } \\
\text { self-empl. }\end{array}$ & $\begin{array}{c}\text { Other } \\
\text { sources }\end{array}$ \\
\hline \multicolumn{9}{|c|}{ Panel A. Difference-in-difference } \\
\hline Post*Treatment & $\begin{array}{l}-0.14 \\
(0.09)\end{array}$ & $\begin{array}{l}-0.05 \\
(0.16)\end{array}$ & $\begin{array}{l}-0.36^{*} \\
(0.19)\end{array}$ & $\begin{array}{c}0.30 \\
(0.29)\end{array}$ & $\begin{array}{l}-0.03 \\
(0.09)\end{array}$ & $\begin{array}{c}1.01 * * * \\
(0.17)\end{array}$ & $\begin{array}{c}0.03 \\
(0.10)\end{array}$ & $\begin{array}{l}-0.34 * \\
(0.20)\end{array}$ \\
\hline $\begin{array}{l}\text { Post ( } 0 \text { if baseline, } 1 \text { if } \\
\text { endline) }\end{array}$ & $0.74^{* * *}$ & -0.12 & 0.21 & -0.08 & 0.10 & -0.04 & $-0.27 * * *$ & $2.75 * * *$ \\
\hline & $(0.07)$ & $(0.12)$ & $(0.15)$ & $(0.21)$ & $(0.07)$ & $(0.03)$ & $(0.07)$ & $(0.14)$ \\
\hline Constant & $\begin{array}{c}5.30 * * * \\
(0.05)\end{array}$ & $\begin{array}{c}0.56^{* * * *} \\
(0.08)\end{array}$ & $\begin{array}{c}4.44 * * * \\
(0.11)\end{array}$ & $\begin{array}{c}1.85^{* * * *} \\
(0.14)\end{array}$ & $\begin{array}{c}0.01 \\
(0.05)\end{array}$ & $\begin{array}{l}0.15^{* *} \\
(0.07)\end{array}$ & $\begin{array}{c}0.38 * * * \\
(0.06)\end{array}$ & $\begin{array}{c}0.75^{* * * *} \\
(0.09)\end{array}$ \\
\hline Observations & 1,976 & 1,928 & 1,991 & 1,938 & 1,987 & 1,910 & 1,967 & 1,777 \\
\hline R-squared & 0.152 & 0.012 & 0.016 & 0.010 & 0.012 & 0.129 & 0.025 & 0.382 \\
\hline $\begin{array}{l}\text { Mean of dep. var. at } \\
\text { baseline }\end{array}$ & 318 & 15 & 178 & 57 & 7 & 4 & 37 & 38 \\
\hline \multicolumn{9}{|c|}{ Panel B. First difference, Treatment group only } \\
\hline $\begin{array}{l}\text { Post ( } 0 \text { if baseline, } 1 \text { if } \\
\text { endline) }\end{array}$ & $0.62^{* * *}$ & -0.17 & -0.09 & 0.19 & 0.06 & $0.97 * * *$ & $-0.25^{* * *}$ & $2.42 * * *$ \\
\hline & $(0.05)$ & $(0.10)$ & $(0.13)$ & $(0.19)$ & $(0.06)$ & $(0.16)$ & $(0.07)$ & $(0.14)$ \\
\hline Constant & $\begin{array}{c}5.31^{* * *} \\
(0.07)\end{array}$ & $\begin{array}{c}0.42^{* * * *} \\
(0.12)\end{array}$ & $\begin{array}{c}4.42 * * * \\
(0.18)\end{array}$ & $\begin{array}{c}1.55^{* * * *} \\
(0.20)\end{array}$ & $\begin{array}{l}-0.06 \\
(0.08)\end{array}$ & $\begin{array}{l}0.21 * \\
(0.12)\end{array}$ & $\begin{array}{c}0.42 * * * \\
(0.09)\end{array}$ & $\begin{array}{c}0.80^{* * * *} \\
(0.12)\end{array}$ \\
\hline Observations & 1,090 & 1,064 & 1,100 & 1,075 & 1,100 & 1,031 & 1,091 & 965 \\
\hline R-squared & 0.138 & 0.031 & 0.007 & 0.010 & 0.019 & 0.139 & 0.023 & 0.334 \\
\hline $\begin{array}{l}\text { Mean of dep. var. at } \\
\text { baseline }\end{array}$ & 318 & 15 & 178 & 57 & 7 & 4 & 37 & 38 \\
\hline \multicolumn{9}{|c|}{ Panel C. Cross-section with endline data } \\
\hline $\begin{array}{l}\text { Treatment ( } 1 \text { if } \mathrm{T} \\
\text { group, } 0 \text { if } \mathrm{C} \text { group) }\end{array}$ & -0.03 & 0.00 & $-0.35^{* *}$ & 0.04 & -0.10 & $1.11 * * *$ & $0.07 *$ & -0.06 \\
\hline & $(0.05)$ & $(0.12)$ & $(0.18)$ & $(0.22)$ & $(0.07)$ & $(0.16)$ & $(0.04)$ & $(0.11)$ \\
\hline Constant & $\begin{array}{c}6.13^{* * * *} \\
(0.05)\end{array}$ & $\begin{array}{c}0.39 * * * \\
(0.12)\end{array}$ & $\begin{array}{c}4.73 * * * \\
(0.18)\end{array}$ & $\begin{array}{c}2.12 * * * \\
(0.23)\end{array}$ & $\begin{array}{l}0.16^{* *} \\
(0.07)\end{array}$ & $\begin{array}{c}0.13 \\
(0.10)\end{array}$ & $\begin{array}{l}0.06^{*} \\
(0.04)\end{array}$ & $\begin{array}{c}3.50 * * * \\
(0.13)\end{array}$ \\
\hline Observations & 985 & 968 & 995 & 953 & 995 & 941 & 998 & 940 \\
\hline R-squared & 0.007 & 0.007 & 0.010 & 0.010 & 0.007 & 0.114 & 0.013 & 0.021 \\
\hline $\begin{array}{l}\text { Mean of dep. var. at } \\
\text { baseline (full sample) }\end{array}$ & 313 & 13 & 175 & 58 & 7 & 3 & 37 & 38 \\
\hline
\end{tabular}

Notes: $* * * \mathrm{p}<0.01, * * \mathrm{p}<0.05, * \mathrm{p}<0.1$. All regressions include village-level fixed effects. Standard errors are clustered at the village level. Variables controlling for unbalanced characteristics of the sample (baseline values of whether the household saves, participates in EGS, receives a pension, has outstanding loan(s) from self-help groups, and own an animal) are included in the regressions but not shown. The dependent variables are the log of the monthly per capita income from each source (log of $1+$ amount in 2007 Rupees; 1 USD $\approx 40$ Rs). The means of the dependent variables at baseline are in level form. Livestock income includes income from irregular sales of animals. Other sources of income include land sales, rental, government assistance, remittances, pensions and other unclassified sources. 
Table 7. Impact of the Ultra-Poor Program on Time Use of Adults and Children

\begin{tabular}{|c|c|c|c|c|c|c|}
\hline & $\begin{array}{l}\text { Productive } \\
\text { time }\end{array}$ & Leisure time & $\begin{array}{c}\text { Time doing } \\
\text { chores }\end{array}$ & Agr. Labor & $\begin{array}{l}\text { Tending } \\
\text { animals }\end{array}$ & $\begin{array}{c}\text { Tending } \\
\text { animals, if } \\
\text { owns } \\
\text { animals } \\
\end{array}$ \\
\hline \multirow[t]{2}{*}{ Post*Treatment } & -21 & 8 & 12 & $-59 * *$ & $16 * * *$ & 50 \\
\hline & $(25)$ & (5) & (13) & $(24)$ & (4) & $(43)$ \\
\hline \multirow[t]{2}{*}{$\begin{array}{l}\text { Post ( } 0 \text { if baseline, } 1 \text { if } \\
\text { endline) }\end{array}$} & $71 * * *$ & $-13 * * *$ & $-50 * * *$ & $44 * *$ & $-6 * *$ & $-72 *$ \\
\hline & (19) & (4) & (8) & (17) & (2) & $(40)$ \\
\hline \multirow[t]{2}{*}{ Constant } & $309 * * *$ & $23 * * *$ & $226 * * *$ & $254 * * *$ & $7 * * *$ & $106 * * *$ \\
\hline & (12) & (3) & (7) & (13) & (2) & (29) \\
\hline Observations & 2,000 & 2,000 & 2,000 & 1,981 & 1,994 & 298 \\
\hline R-squared & 0.032 & 0.014 & 0.053 & 0.017 & 0.028 & 0.076 \\
\hline $\begin{array}{l}\text { Mean of dep. var. at } \\
\text { baseline }\end{array}$ & 326 & 26 & 226 & 272 & 7 & 53 \\
\hline
\end{tabular}

Notes: $* * * \mathrm{p}<0.01, * * \mathrm{p}<0.05, * \mathrm{p}<0.1$. All regressions include village-level fixed effects. Standard errors are clustered at the village level. Variables controlling for unbalanced characteristics of the sample (baseline values of whether the household saves, participates in EGS, receives a pension, has outstanding loan(s) from self-help groups, and own an animal) are included in the regressions but not shown. Number of households owning animals: baseline $=73$, endline $=186$. Time is measured in minutes in the last 24 hours. Productive time includes working in the field, tending animals, working in business, agricultural labor, working in someone else's house, non-agricultural labor and doing other work. Leisure time includes shopping, watching TV/listening to radio and doing political activities. Time doing chores includes gathering water and fuel, cooking, cleaning home and clothes and caring for children/elderly. Animal ownership is measured in each wave. 
Table 8. Impact of the Ultra-Poor Program on Expenditures

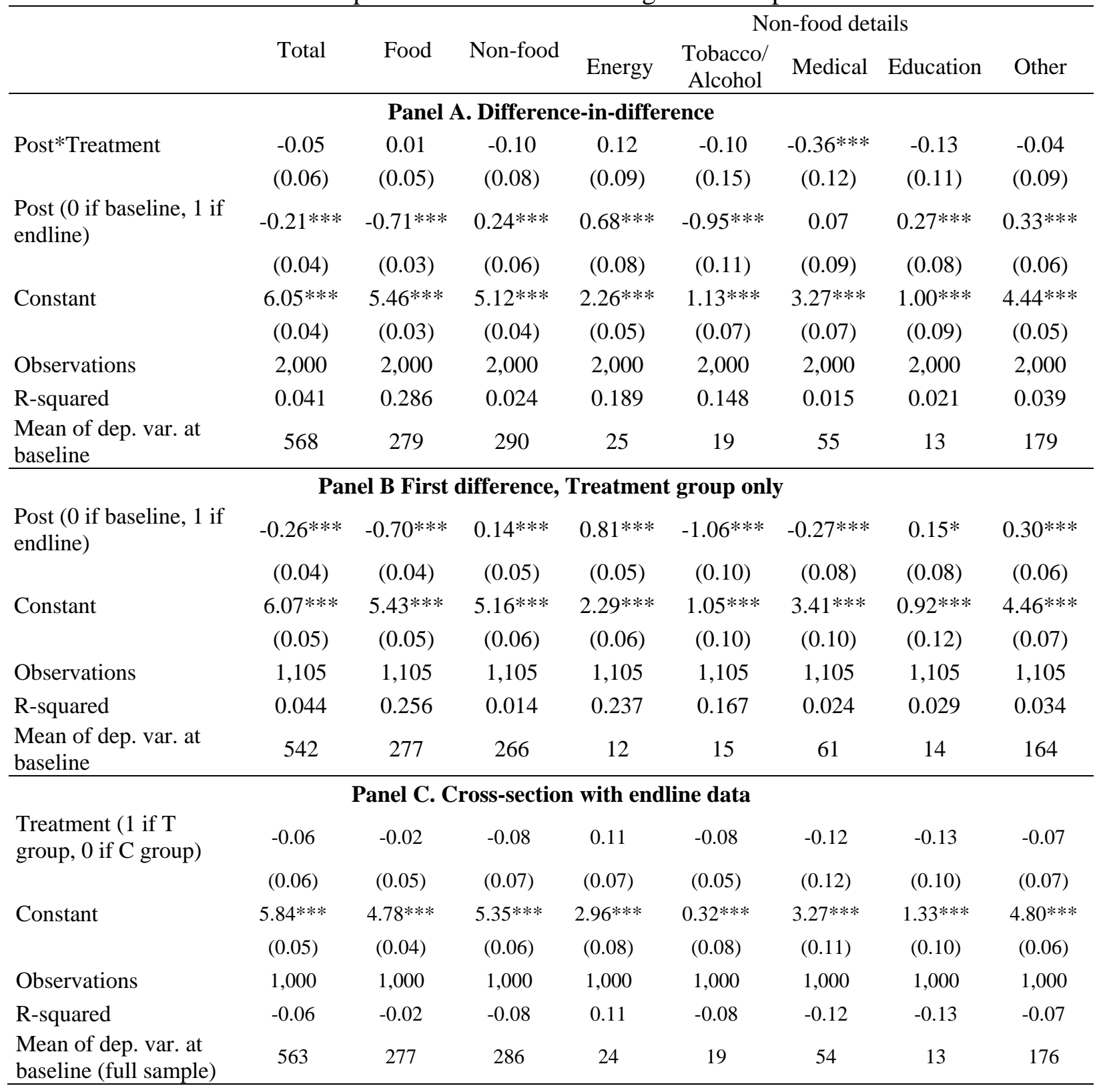

Notes: $* * * \mathrm{p}<0.01, * * \mathrm{p}<0.05, * \mathrm{p}<0.1$. All regressions include village-level fixed effects. Standard errors are clustered at the village level. Variables controlling for unbalanced characteristics of the sample (baseline values of whether the household saves, participates in EGS, receives a pension, has outstanding loan(s) from self-help groups, and own an animal) are included in the regressions but not shown. The dependent variables are the $\log$ of the monthly per capita expenditures in each category ( $\log$ of $1+$ amount in 2007 Rupees; 1 USD $\approx 40$ Rs). The means of the dependent variables at baseline are in level form. Energy expenditures includes expenditures on electricity, other forms of energy (e.g., kerosene for lamps), and own vehicle fuel. Other expenditures include general household expenditures (household products, personal care products, clothing, phone, rent, utilities), transportation, entertainment, ceremonial expenditures, and unspecified expenditures. 
Table 9. Impact of the Ultra-Poor Program on Loans and Savings

\begin{tabular}{lcccccc}
\hline & $\begin{array}{c}\text { Household } \\
\text { has } \\
\text { outstanding } \\
\text { loans? }\end{array}$ & $\begin{array}{c}\text { Number of } \\
\text { loans } \\
\text { outstanding }\end{array}$ & $\begin{array}{c}\text { Log (Amount } \\
\text { of loan } \\
\text { outstanding) }\end{array}$ & $\begin{array}{c}\text { Household } \\
\text { saves? }\end{array}$ & $\begin{array}{c}\text { Log (Total } \\
\text { savings } \\
\text { balance) }\end{array}$ \\
\hline Post*Treatment & -0.030 & -0.09 & -0.13 & -0.039 & -0.37 & $(0.43)$ \\
Post (0 if baseline, 1 if endline) & $(0.059)$ & $(0.09)$ & $(0.45)$ & $(0.051)$ & $0.090 * *$ & $0.90 * * *$ \\
Constant & $(0.223 * * *$ & $-0.33 * * *$ & $-1.92 * * *$ & $(0.34)$ & $(0.038)$ & $(0.34)$ \\
Observations & $0.568 * * *$ & $0.69 * * *$ & $4.23 * * *$ & $0.227 * * *$ & $0.52 * * *$ & $(0.14)$ \\
R-squared & $(0.025)$ & $(0.04)$ & $(0.19)$ & $(0.020)$ & 2,018 & 1,344 \\
Mean of dep. var. at baseline & 2,000 & 2,018 & 2,018 & 0.322 & 0.219 \\
\hline
\end{tabular}

Notes: $* * * \mathrm{p}<0.01, * * \mathrm{p}<0.05, * \mathrm{p}<0.1$. All regressions include village-level fixed effects. Standard errors are clustered at the village level. Regressions in which the dependent variable is a binary variable are run as linear probability models. Variables controlling for unbalanced characteristics of the sample (baseline values of whether the household saves, participates in EGS, receives a pension, has outstanding loan(s) from self-help groups, and own an animal) are included in the regressions but not shown. The amounts of loan outstanding and savings balance are in $\log$ form $(\log$ of $1+$ amount in 2007 Rupees; 1 USD $\approx 40 \mathrm{Rs})$. The means of these dependent variables at baseline are in level form. 
Table 10. Impact of the Ultra-Poor Program on the Use of Government Safety Nets

\begin{tabular}{|c|c|c|c|c|c|c|c|c|}
\hline & \multicolumn{6}{|c|}{ Household sought or received the following: } & \multirow{2}{*}{$\begin{array}{l}\text { Received } \\
\text { goods } \\
\text { from PDS }\end{array}$} & \multirow{2}{*}{$\begin{array}{l}\text { Received } \\
\text { goods } \\
\text { from BPL }\end{array}$} \\
\hline & $\begin{array}{c}\text { work } \\
\text { from EGS }\end{array}$ & pension & $\begin{array}{c}\text { govt. } \\
\text { housing }\end{array}$ & $\begin{array}{c}\text { govt. } \\
\text { assets }\end{array}$ & $\begin{array}{l}\text { govt. } \\
\text { training }\end{array}$ & $\begin{array}{c}\text { subsidized } \\
\text { loans }\end{array}$ & & \\
\hline \multirow[t]{2}{*}{ Post*Treatment } & -0.080 & -0.085 & 0.045 & -0.011 & -0.010 & -0.010 & -0.000 & 0.002 \\
\hline & $(0.052)$ & $(0.061)$ & $(0.048)$ & $(0.036)$ & $(0.034)$ & $(0.014)$ & $(0.017)$ & $(0.021)$ \\
\hline \multirow{2}{*}{$\begin{array}{l}\text { Post ( } 0 \text { if baseline, } 1 \text { if } \\
\text { endline) }\end{array}$} & $0.510 * * *$ & 0.062 & 0.011 & $0.063^{* *}$ & $0.070 * * *$ & $0.020 *$ & $0.054 * * *$ & $0.053 * * *$ \\
\hline & $(0.035)$ & $(0.043)$ & $(0.033)$ & $(0.026)$ & $(0.025)$ & $(0.011)$ & $(0.013)$ & $(0.017)$ \\
\hline \multirow[t]{2}{*}{ Constant } & $0.147 * * *$ & $0.292 * * *$ & $0.130 * * *$ & $0.032 * * *$ & 0.012 & $0.030 * * *$ & $0.878 * * *$ & $0.866 * * *$ \\
\hline & $(0.019)$ & $(0.019)$ & $(0.018)$ & $(0.012)$ & $(0.009)$ & $(0.008)$ & $(0.013)$ & $(0.015)$ \\
\hline Observations & 1,998 & 1,998 & 1,997 & 1,999 & 1,998 & 1,997 & 1,999 & 1,977 \\
\hline R-squared & 0.456 & 0.261 & 0.008 & 0.020 & 0.044 & 0.006 & 0.038 & 0.036 \\
\hline $\begin{array}{l}\text { Mean of dep. var. at } \\
\text { baseline }\end{array}$ & 0.344 & 0.643 & 0.168 & 0.039 & 0.005 & 0.023 & 0.926 & 0.918 \\
\hline
\end{tabular}

Notes: $* * * \mathrm{p}<0.01, * * \mathrm{p}<0.05, * \mathrm{p}<0.1$. All regressions include village-level fixed effects. Standard errors are clustered at the village level. Regressions in which the dependent variable is a binary variable are run as linear probability models. Variables controlling for unbalanced characteristics of the sample (baseline values of whether the household saves, participates in EGS, receives a pension, has outstanding loan(s) from self-help groups, and own an animal) are included in the regressions but not shown. EGS include all government "employment-generating schemes," the largest of which is the National Rural Employment Guarantee scheme created by the Mahatma Gandhi National Rural Employment Guarantee Act of 2005. 
Table 11. Impact of the Ultra-Poor Program on Total Monthly Per Capita Income, by Subgroups

\begin{tabular}{|c|c|c|}
\hline Owned animals at baseline? & No animals & Owned animals \\
\hline \multirow[t]{2}{*}{ Post*Treatment } & -0.15 & 0.19 \\
\hline & $(0.09)$ & $(0.23)$ \\
\hline \multirow[t]{2}{*}{ Post ( 0 if baseline; 1 if endline) } & $0.78 * * *$ & 0.28 \\
\hline & $(0.07)$ & $(0.20)$ \\
\hline \multirow[t]{2}{*}{ Constant } & $5.27 * * *$ & $5.32 * * *$ \\
\hline & $(0.05)$ & $(0.23)$ \\
\hline Observations & 1,772 & 204 \\
\hline R-squared & 0.162 & 0.142 \\
\hline Mean of dep. var. at baseline & 313 & 358 \\
\hline Owned land at baseline? & No land & Owned land \\
\hline \multirow[t]{2}{*}{ Post*Treatment } & $-0.21 *$ & -0.08 \\
\hline & $(0.12)$ & $(0.10)$ \\
\hline \multirow[t]{2}{*}{ Post ( 0 if baseline; 1 if endline) } & $0.84 * * *$ & $0.59 * * *$ \\
\hline & $(0.09)$ & $(0.07)$ \\
\hline \multirow[t]{2}{*}{ Constant } & $5.18 * * *$ & $5.59^{* * *}$ \\
\hline & $(0.07)$ & $(0.08)$ \\
\hline Observations & 1,217 & 713 \\
\hline R-squared & 0.168 & 0.176 \\
\hline Mean of dep. var. at baseline & 311 & 323 \\
\hline Owned house at baseline? & No house & Owned house \\
\hline \multirow[t]{2}{*}{ Post*Treatment } & $-0.32 * *$ & -0.06 \\
\hline & $(0.16)$ & $(0.11)$ \\
\hline \multirow[t]{2}{*}{ Post ( 0 if baseline; 1 if endline) } & $0.85^{* * *}$ & $0.70 * * *$ \\
\hline & $(0.12)$ & $(0.09)$ \\
\hline \multirow[t]{2}{*}{ Constant } & $5.16^{* * *}$ & $5.34 * * *$ \\
\hline & $(0.12)$ & $(0.07)$ \\
\hline Observations & 571 & 1,397 \\
\hline R-squared & 0.185 & 0.163 \\
\hline Mean of dep. var. at baseline & 313 & 318 \\
\hline
\end{tabular}

Notes: $* * * \mathrm{p}<0.01, * * \mathrm{p}<0.05, * \mathrm{p}<0.1$. All regressions include village-level fixed effects. Standard errors are clustered at the village level. Variables controlling for unbalanced characteristics of the sample (baseline values of whether the household saves, participates in EGS, receives a pension, has outstanding loan(s) from self-help groups, and own an animal) are included in the regressions but not shown. The dependent variable is the $\log$ of the total monthly per capita income (log of $1+$ amount in 2007 Rupees; 1 USD $\approx 40$ Rs). The means of the dependent variable at baseline are in level form. 
Figure 1. Density of Monthly Per Capita Income and Expenditures

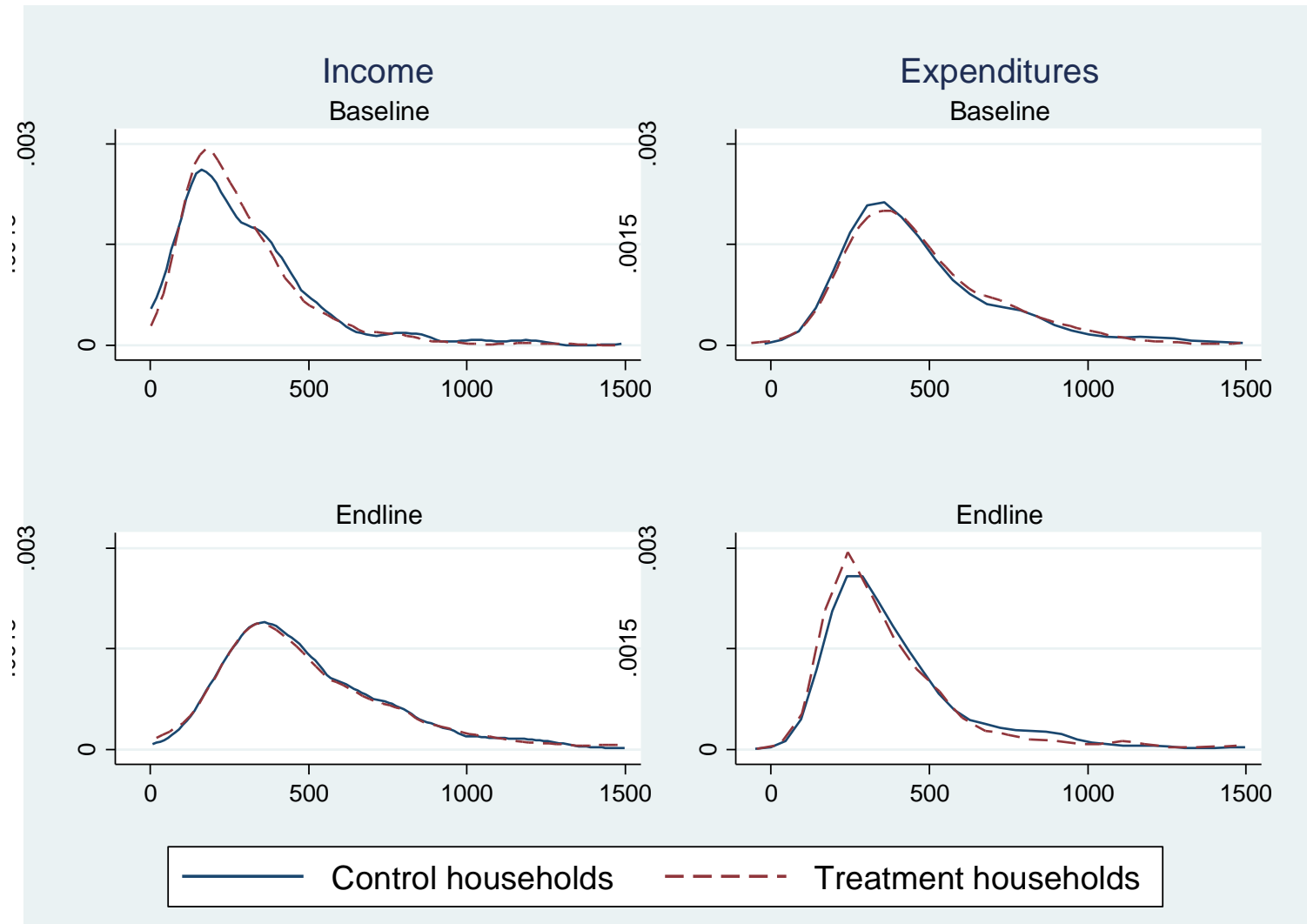

Graph shows distribution of per capita monthly total income and expenditures, truncated at Rs.1,500. Horizontal axes show amounts that are in Rupees of 2007. 
Figure 2. Average Household Monthly Per Capita Income, by Source of Income, Survey Wave and Treatment Assignment

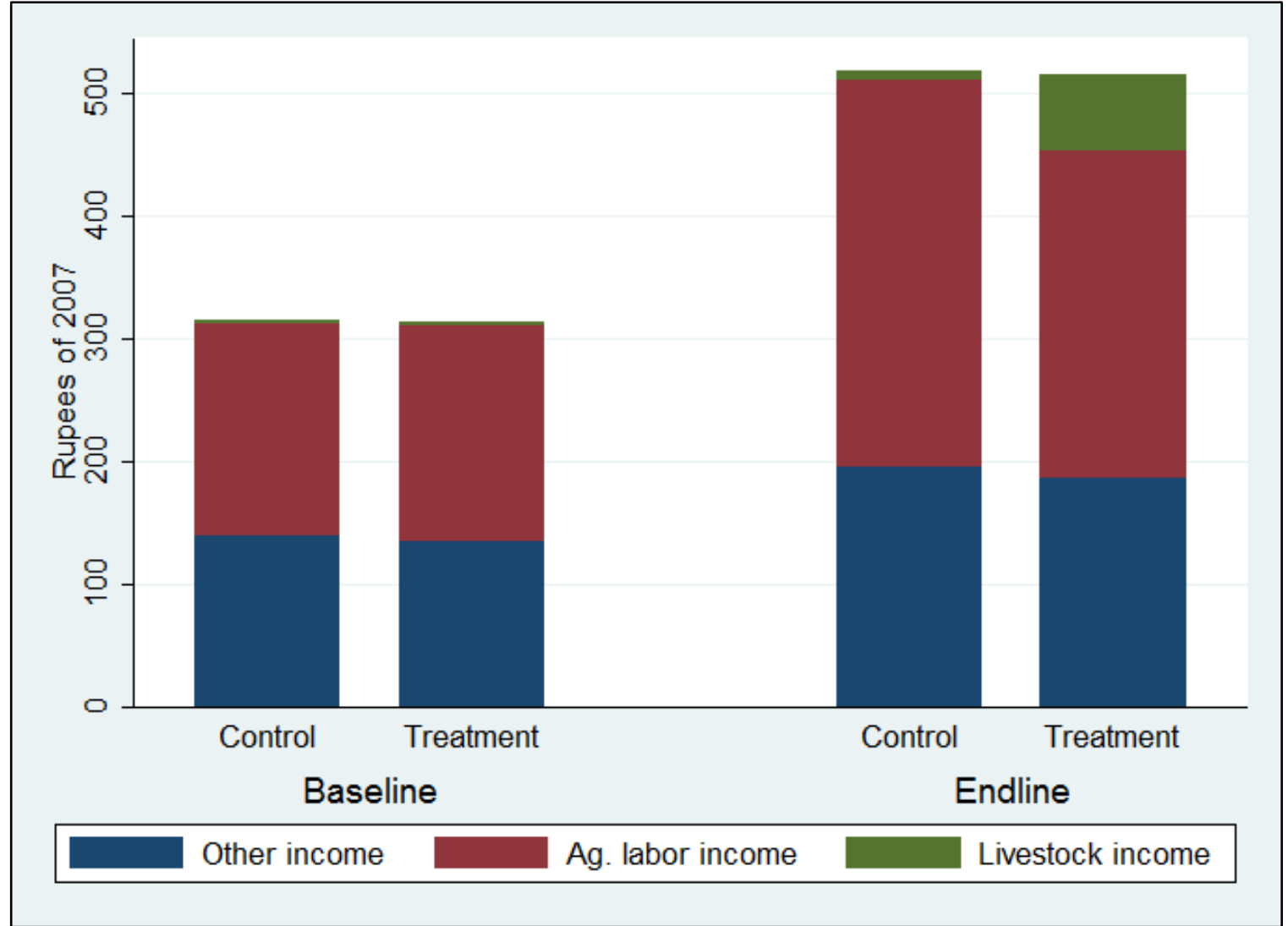

Other sources of income include non-agriculture labor, agriculture and non-agriculture self-employment, salaried employment, and other unclassified sources. 
Figure 3. Density of Monthly Per Capita Food and Non-food Expenditures

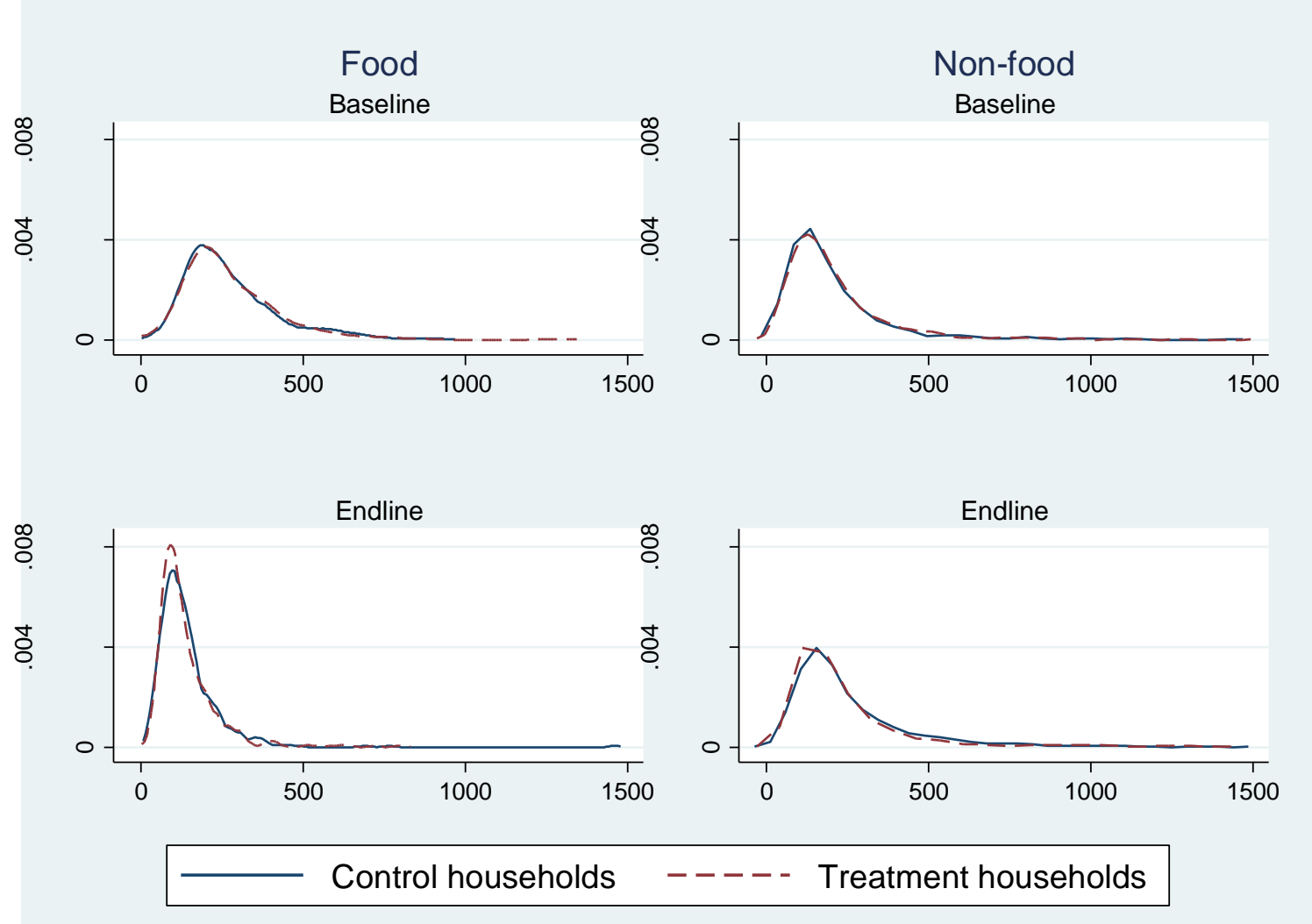

Graph shows distribution of per capita monthly food and non-food expenditures, truncated at Rs.1,500. Horizontal axes show amounts in Rupees of 2007. 
Appendix Table 1. Summary statistics for attrition and non-attrition households.

\begin{tabular}{|c|c|c|c|}
\hline & $\begin{array}{l}\text { Non-attriters } \\
(1,011 \mathrm{hh})\end{array}$ & $\begin{array}{c}\text { Attriters } \\
(53 \mathrm{hh})\end{array}$ & $\mathrm{p}$-value \\
\hline \multicolumn{4}{|l|}{ Individual-level data on household head } \\
\hline Age (years) & 46.4 & 51.9 & $0.012 * *$ \\
\hline Literate $(\%)$ & 4.8 & 11.3 & $0.034 * *$ \\
\hline Marital status: Married (\%) & 18.3 & 18.9 & 0.920 \\
\hline Marital status: Unmarried (\%) & 1.0 & 0.0 & 0.467 \\
\hline Marital status: Divorced (\%) & 13.5 & 15.1 & 0.736 \\
\hline Marital status: Widow (\%) & 67.2 & 66.0 & 0.858 \\
\hline \multicolumn{4}{|l|}{$\underline{\text { Household-level data }}$} \\
\hline Household assigned to the treatment group (\%) & 54.0 & 56.6 & 0.712 \\
\hline Number of household members & 3.3 & 3.3 & 0.843 \\
\hline Average age of household members (years) & 29.4 & 32.9 & $0.056^{*}$ \\
\hline Own their house $(\%)$ & 71.4 & 66.0 & 0.402 \\
\hline House material: Pucca/good (\%) & 1.8 & 1.9 & 0.955 \\
\hline House material: Kuccha/medium (\%) & 80.1 & 81.1 & 0.857 \\
\hline House material: Thatched/bad (\%) & 18.1 & 17.0 & 0.837 \\
\hline Source of drinking water: Tap (\%) & 50.2 & 60.4 & 0.149 \\
\hline Source of drinking water: Well (\%) & 4.7 & 1.9 & 0.345 \\
\hline Source of drinking water: Tube well/hand pump (\%) & 43.8 & 37.7 & 0.389 \\
\hline Source of drinking water: Tank/reservoir (\%) & 1.3 & 0.0 & 0.406 \\
\hline Source of drinking water: Other $(\%)$ & 0.1 & 0.0 & 0.819 \\
\hline Latrine is open air $(\%)$ & 98.8 & 96.2 & 0.109 \\
\hline Any household member migrates for work (\%) & 15.9 & 12.8 & 0.563 \\
\hline Total land owned by hh (acres) & 41.7 & 34.0 & 0.583 \\
\hline Total monthly income per capita (Rs) & 316 & 262 & 0.220 \\
\hline Main source of income: Farming (\%) & 3.1 & 0.0 & 0.196 \\
\hline Main source of income: Livestock (\%) & 0.5 & 0.0 & 0.608 \\
\hline Main source of income: Non-ag. enterprise (\%) & 4.6 & 9.4 & 0.116 \\
\hline Main source of income: Wage labor $(\%)$ & 91.8 & 90.6 & 0.753 \\
\hline Total monthly expenditures per capita (Rs) & 568 & 471 & 0.273 \\
\hline Household has outstanding loans (\%) & 71.4 & 67.9 & 0.585 \\
\hline Household saves (\%) & 56 & 47.2 & 0.209 \\
\hline Sought or received work from EGS (\%) & 34.4 & 30.8 & 0.595 \\
\hline Sought or received a pension $(\%)$ & 64.6 & 66 & 0.826 \\
\hline Sought or received government-subsidized loans (\%) & 2.3 & 3.8 & 0.483 \\
\hline Has an Antodaya, pink or white card (\%) & 92.7 & 94.3 & 0.649 \\
\hline Receives BPL rations $(\%)$ & 91.9 & 94.2 & 0.546 \\
\hline
\end{tabular}


Appendix Table 2. Summary statistics for control and treatment households at baseline.

\begin{tabular}{|c|c|c|c|c|c|}
\hline & $\begin{array}{l}\text { Control } \\
\text { group }\end{array}$ & $\mathrm{N}$ & $\begin{array}{l}\text { Treatment } \\
\text { group }\end{array}$ & $\mathrm{N}$ & p-value \\
\hline \multicolumn{6}{|l|}{ Individual-level data on ultra-poor participant } \\
\hline Age (years) & 37.6 & 446 & 38.6 & 507 & 0.159 \\
\hline Literate $(\%)$ & 4.3 & 446 & 4.7 & 508 & 0.731 \\
\hline Marital status: Married (\%) & 7.8 & 446 & 9.6 & 508 & 0.329 \\
\hline Marital status: Unmarried (\%) & 1.3 & 446 & 3.1 & 508 & $0.064 *$ \\
\hline Marital status: Divorced (\%) & 25.6 & 446 & 20.1 & 508 & $0.044 * *$ \\
\hline Marital status: Widow (\%) & 65.2 & 446 & 67.1 & 508 & 0.541 \\
\hline \multicolumn{6}{|l|}{$\underline{\text { Household-level data }}$} \\
\hline Number of household members & 3.2 & 465 & 3.3 & 546 & 0.142 \\
\hline Average age of household members (years) & 28.7 & 465 & 30.1 & 546 & $0.097^{*}$ \\
\hline Own their house $(\%)$ & 72.6 & 463 & 70.4 & 544 & 0.449 \\
\hline House material: Pucca/good (\%) & 2.4 & 465 & 1.3 & 546 & 0.195 \\
\hline House material: Kuccha/medium (\%) & 78.9 & 465 & 81.1 & 546 & 0.381 \\
\hline House material: Thatched/bad (\%) & 18.7 & 465 & 17.6 & 546 & 0.643 \\
\hline Source of drinking water: Tap (\%) & 51.8 & 465 & 48.8 & 545 & 0.339 \\
\hline Source of drinking water: Well $(\%)$ & 4.1 & 465 & 5.1 & 545 & 0.430 \\
\hline Source of drinking water: Tube well/hand pump (\%) & 43.4 & 465 & 44.0 & 545 & 0.849 \\
\hline Source of drinking water: Tank/reservoir $(\%)$ & 0.4 & 465 & 2.0 & 545 & $0.026 * *$ \\
\hline Source of drinking water: Other $(\%)$ & 0.2 & 465 & 0.0 & 545 & 0.279 \\
\hline Latrine is open air $(\%)$ & 98.7 & 462 & 98.9 & 544 & 0.776 \\
\hline Any household member migrates for work (\%) & 17.1 & 438 & 14.9 & 504 & 0.349 \\
\hline Total land owned by household (acres) & 0.39 & 455 & 0.44 & 530 & 0.459 \\
\hline Total monthly income per capita (Rs) & 315 & 461 & 316 & 544 & 0.938 \\
\hline Main source of income: Farming (\%) & 2.6 & 465 & 3.5 & 546 & 0.409 \\
\hline Main source of income: Livestock (\%) & 0.6 & 465 & 0.4 & 546 & 0.529 \\
\hline Main source of income: Non-agr. enterprise (\%) & 4.7 & 465 & 4.6 & 546 & 0.909 \\
\hline Main source of income: Wage labor $(\%)$ & 92.0 & 465 & 91.6 & 546 & 0.787 \\
\hline Total monthly expenditures per capita (Rs) & 594 & 465 & 545 & 546 & 0.222 \\
\hline Household has outstanding loans (\%) & 68.6 & 465 & 73.8 & 546 & $0.068 *$ \\
\hline Household saves (\%) & 51.0 & 465 & 60.3 & 546 & $0.003 * * *$ \\
\hline Sought or received work from EGS (\%) & 30.8 & 465 & 37.4 & 545 & $0.026^{* *}$ \\
\hline Sought or received a pension $(\%)$ & 60.4 & 465 & 68.1 & 545 & $0.011 * *$ \\
\hline Sought or received government-subsidized loans (\%) & 2.8 & 465 & 1.8 & 546 & 0.306 \\
\hline Has an Antodaya, pink or white card (\%) & 92.5 & 464 & 92.9 & 546 & 0.808 \\
\hline Receives BPL rations (\%) & 91.0 & 456 & 92.6 & 544 & 0.345 \\
\hline Household owns one or more animal(s) (\%) & 7.3 & 463 & 13.0 & 540 & $0.004 * * *$ \\
\hline Experienced an event (shock) in last 12 months (\%) & 31.8 & 465 & 34.2 & 546 & 0.416 \\
\hline
\end{tabular}


Appendix Table 3. Impact of the ultra-poor program on food security.

\begin{tabular}{lccccc}
\hline & $\begin{array}{c}\text { Adults cut } \\
\text { size or skip } \\
\text { meals? }\end{array}$ & $\begin{array}{c}\text { Adults do not } \\
\text { eat for whole } \\
\text { day? }\end{array}$ & $\begin{array}{c}\text { Children } \\
\text { under 16 cut } \\
\text { size or skip } \\
\text { meal? }\end{array}$ & $\begin{array}{c}\text { All } \\
\text { household } \\
\text { members } \\
\text { have enough } \\
\text { food every } \\
\text { day, all year? }\end{array}$ & $\begin{array}{c}\text { Everyone in } \\
\text { household } \\
\text { eats two } \\
\text { meals per } \\
\text { day? }\end{array}$ \\
\hline Post*Treatment & -0.039 & -0.056 & -0.050 & -0.032 & -0.014 \\
Post (0 if baseline, 1 if endline) & $(0.051)$ & $(0.044)$ & $(0.039)$ & $(0.045)$ & $(0.026)$ \\
Constant & $-0.187 * * *$ & -0.023 & $0.120^{* * *}$ & $0.191 * * *$ & 0.020 \\
& $(0.040)$ & $(0.033)$ & $(0.030)$ & $(0.031)$ & $(0.020)$ \\
Number of observations & $0.357^{* * *}$ & $0.174 * * *$ & 0.033 & $0.719^{* * *}$ & $0.928^{* * *}$ \\
R-squared & $(0.023)$ & $(0.017)$ & $(0.022)$ & $(0.018)$ & $(0.014)$ \\
Mean of dep. var. at baseline & 1,572 & 1,553 & 1,067 & 1,964 & 1,980 \\
& 0.072 & 0.014 & 0.039 & 0.063 & 0.004 \\
p & 0.354 & 0.172 & 0.042 & 0.719 & 0.931 \\
\hline
\end{tabular}

$* * * \mathrm{p}<0.01, * * \mathrm{p}<0.05, * \mathrm{p}<0.1$. All regressions include village-level fixed effects. Standard errors are clustered at the village level. All regressions are run as linear probability models. Variables controlling for unbalanced characteristics of the sample (baseline values of whether the household saves, participates in EGS, receives a pension, has outstanding loan(s) from selfhelp groups, and own an animal) are included in the regressions but not shown. Sample sizes are low in the baseline/endline analysis because of many missing values. 
Appendix Table 4. Impact of the ultra-poor program on measures of physical health.

\begin{tabular}{lccc}
\hline & $\begin{array}{c}\text { Felt that physical } \\
\text { health improved in } \\
\text { last year? }\end{array}$ & $\begin{array}{c}\text { Number of days } \\
\text { unable to work } \\
\text { because of illness }\end{array}$ & $\begin{array}{c}\text { Any member went to } \\
\text { the doctor/ hospital in } \\
\text { last year? }\end{array}$ \\
\hline Post*Treatment & -0.009 & -0.400 & -0.053 \\
Post (0 if baseline, 1 if endline) & $(0.061)$ & $(0.558)$ & $(0.065)$ \\
& -0.055 & $-0.924^{* *}$ & $-0.083^{*}$ \\
Constant & $(0.046)$ & $(0.396)$ & $(0.049)$ \\
& $0.223^{* * *}$ & $3.281^{* * *}$ & $0.506^{* * *}$ \\
Number of observations & $(0.022)$ & $(0.272)$ & $(0.029)$ \\
R-squared & 1,982 & 1,958 & 1,836 \\
Mean of dep. var. at baseline & 0.012 & 0.020 & 0.018 \\
\hline
\end{tabular}

$* * * \mathrm{p}<0.01, * * \mathrm{p}<0.05, * \mathrm{p}<0.1$. All regressions include village-level fixed effects. Standard errors are clustered at the village level. Regressions in which the dependent variable is a binary variable are run as linear probability models. Variables controlling for unbalanced characteristics of the sample (baseline values of whether the household saves, participates in EGS, receives a pension, has outstanding loan(s) from self-help groups, and own an animal) are included in the regressions but not shown. 
Appendix Table 5. Impact of the ultra-poor program on access to credit.

\begin{tabular}{lcccccc}
\hline & Family & Com. bank & Grameen & SHG & $\begin{array}{c}\text { Money- } \\
\text { lender }\end{array}$ & Friend \\
\hline Post*Treatment & -0.003 & 0.006 & 0.011 & -0.041 & -0.015 & 0.005 \\
& $(0.031)$ & $(0.037)$ & $(0.032)$ & $(0.083)$ & $(0.075)$ & $(0.011)$ \\
Post (0 if baseline, 1 if endline) & $-0.081^{* * *}$ & 0.031 & -0.008 & $0.214^{* * *}$ & $-0.239^{* * *}$ & $-0.015^{* *}$ \\
& $(0.024)$ & $(0.030)$ & $(0.024)$ & $(0.068)$ & $(0.050)$ & $(0.007)$ \\
Constant & $0.155^{* * *}$ & $0.047^{* * *}$ & $0.064^{* * *}$ & $0.131^{* * *}$ & $0.540^{* * *}$ & $0.019^{* *}$ \\
& $(0.018)$ & $(0.015)$ & $(0.018)$ & $(0.026)$ & $(0.034)$ & $(0.007)$ \\
Number of observations & 1,183 & 1,183 & 1,183 & 1,183 & 1,183 & 1,183 \\
R-squared & 0.052 & 0.012 & 0.004 & 0.404 & 0.109 & 0.009 \\
Mean of dep. var. at baseline & 0.118 & 0.028 & 0.066 & 0.487 & 0.416 & 0.020 \\
\hline & Neighbor & Shop- & Co- & MFI & Other & \\
& & keeper & operative & & & \\
\hline Post*Treatment & 0.001 & 0.005 & -0.014 & -0.012 & 0.007 & \\
Post (0 if baseline, 1 if endline) & $-0.086^{* * *}$ & $-0.012^{* *}$ & $0.060^{* *}$ & $0.041^{* * *}$ & -0.004 & \\
& $(0.022)$ & $(0.006)$ & $(0.025)$ & $(0.014)$ & $(0.008)$ & \\
Constant & $0.145^{* * *}$ & $0.016^{*}$ & 0.017 & 0.002 & 0.004 & \\
Number of observations & $(0.023)$ & $(0.009)$ & $(0.011)$ & $(0.009)$ & $(0.005)$ & \\
R-squared & 1,183 & 1,183 & 1,183 & 1,183 & 1,183 & \\
Mean of dep. var. at baseline & 0.033 & 0.010 & 0.028 & 0.028 & 0.005 & \\
\hline & 0.123 & 0.015 & 0.011 & 0.003 & 0.015 &
\end{tabular}

$* * * \mathrm{p}<0.01, * * \mathrm{p}<0.05, * \mathrm{p}<0.1$. All regressions include village-level fixed effects. Standard errors are clustered at the village level. All regressions are run as linear probability models. Variables controlling for unbalanced characteristics of the sample (baseline values of whether the household saves, participates in EGS, receives a pension, has outstanding loan(s) from self-help groups, and own an animal) are included in the regressions but not shown. The dependent variables are binary variables set to 1 if any household member has one or more outstanding loans from that source, conditional on having one or more outstanding loans. 


\section{Center for Economic Institutions Working Paper Series}

2000-1 Jean Tirole, “Corporate Governance”, January 2000.

2000-2 Kenneth A. Kim and S. Ghon Rhee, “A Note on Shareholder Oversight and the Regulatory Environment: The Japanese Banking Experience”, January 2000.

2000-3 S. Ghon Rhee, "Further Reforms after the "BIG BANG": The JapaneseGovernment Bond Market", June 2000.

2000-4 Stijn Claessens, Simeon Djankov, Joseph Fan, and Larry Lang, "Expropriation of Minority Shareholders in East Asia”, July 2000.

2000-5 Stijn Claessens, Simeon Djankov, Joseph Fan , and Larry Lang, "The Costs of Group Affiliation: Evidence from East Asia”, July 2000.

2001-1 Masaharu Hanazaki and Akie Takeuchi, “An International Comparison of Corporate Investment Behavior -Some Implications for the Governance Structure in Japan-”, February 2001.

2001-2 Katsuyuki Kubo, "The Determinants of Executive Compensation in Japan and the UK: Agency Hypothesis or Joint Determination Hypothesis?”, February 2001.

2001-3 Katsuyuki Kubo, “Changes in Directors' Incentive Plans and the Performance of Firms in the UK”, March 2001.

2001-4 Yupana Wiwattanakantang, "Controlling Shareholders and Corporate Value: Evidence from Thailand", March 2001.

2001-5 Katsuyuki Kubo, “The Effect of Managerial Ownership on Firm Performance: Case in Japan”, March 2001.

2001-6 Didier Guillot and James R. Lincoln, "The Permeability of Network Boundaries: Strategic Alliances in the Japanese Electronics Industry in the 1990s", March 2001.

2001-7 Naohito Abe, “Ageing and its Macroeconomic Implications-A Case in Japan-”, May 2001.

2001-8 Yupana Wiwattanakantang, “The Equity Ownership Structure of Thai Firms”, July 2001.

2001-9 Megumi Suto, "Capital Structure and Investment Behaviour of Malaysian Firms in the 1990s--A study of Corporate Governance before the Crisis--”, August 2001.

2001-10 Naohito Abe, Noel Gaston, and Katsuyuki Kubo, "Executive Pay in Japan : The Role of Bank-Appointed Monitors and the Main Bank Relationship”, September 2001.

2001-11 Colin Mayer, "The Financing and Governance of New Technologies”, September 2001.

2001-12 Masaharu Hanazaki and Akiyoshi Horiuchi, "Can the Financial Restraint Hypothesis Explain Japan’s Postwar Experience?”, September 2001.

2001-13 Shin-ichi Fukuda, "The Role of Long-term Loans for Economic Development: Empirical Evidence in Japan, Korea, and Taiwan”, September 2001. 
2001-14 S. Ghon Rhee, "Further Reforms of the JGB Market for the Promotion of Regional Bond Markets", September 2001.

2001-15 Stijn Claessens, Simeon Djankov, Joseph P. H. Fan, and Larry H. P. Lang, ”The Benefits and Costs of Internal Markets: Evidence from Asia’s Financial Crisis", September 2001.

2001-16 Kenneth A. Kim and John R. Nofsinger, "Institutional Herding, Business Groups, and Economic Regimes: Evidence from Japan”, September 2001.

2001-17 Mitsuhiro Fukao, "Financial Deregulations, Weakness of Market Discipline, and Market Development: Japan's Experience and Lessons for Developing Countries”, September 2001.

2001-18 Akio Kuroda and Koichi Hamada, "Towards an Incentive Compatible Financial System: Accounting and Managing the Non-Performing Loans”, September 2001.

2001-19 Randall Morck and Bernard Yeung, "Japanese Economic Success and the Curious Characteristics of Japanese Stock Prices”, September 2001.

2001-20 Miguel A. García-Cestona, "Ownership Structure, Banks and the Role of Stakeholders: The Spanish Case”, September 2001.

2001-21 Joseph P. H. Fan and T. J. Wong, "Corporate Ownership Structure and the Informativeness of Accounting Earnings in East Asia”, September 2001.

2001-22 Heather Montgomery, “The Effect of the Basel Accord on Bank Lending in Japan”, September 2001.

2001-23 Naoyuki Yoshino, Sahoko Kaji, and Ayako Suzuki, "The Basket-peg, Dollar-peg and Floating---A Comparative Analysis of Exchange Rate Regimes”, September 2001.

2001-24 Colin Mayer, Koen Schoors, and Yishay Yafeh, "Sources of Funds and Investment Strategies of Venture Capital Funds: Evidence from Germany, Israel, Japan and the UK", September 2001.

2001-25 Yukinobu Kitamura, Megumi Suto, and Juro Teranishi, "Towards a New Architecture for the Japanese Financial System: Participation Costs, Intermediated Ownership and Wealth Distribution", September 2001.

2002-1 Evgeni Peev, "The Political Economy of Corporate Governance Change in Bulgaria: Washington Consensus, Primitive Accumulation of Capital, and Catching-Up in the 1990", March 2002.

2002-2 Naohito Abe, "Saving, Capital Flows, and the Symmetric International Spillover of Industrial Policies", June 2002.

2002-3 Masaharu Hanazaki and Akiyoshi Horiuchi, “A Review of Japan's Bank Crisis from the Governance Perspective”, July 2002.

2002-4 Chutathong Charumirind, Raja Kali and Yupana Wiwattanakantang, "Crony Lending: Thailand before the Financial Crisis", September 2002.

2002-5 Maitreesh Ghatak and Raja Kali, "Financially Interlinked Business Groups" , September 2002.

2002-6 Tarun Khanna, Joe Kogan, and Krishna Palepu, "Globalization and Similarities in Corporate Governance: A Cross-Country Analysis”, September 2002. 
2002-7 Chongwoo Choe, "Delegated Contracting and Corporate Hierarchies”, September 2002.

2002-8 Tarun Khanna and Yishay Yafeh, "Business Groups and Risk Sharing around the World", September 2002.

2002-9 Yitae Kim, Kwangwoo Park, Ronald A. Ratti, and Hyun-Han Shin, "Do Main Banks Extract Rents from their Client Firms? Evidence from Korean Chaebol”, September 2002.

2002-10 Armen Hovakimian, Edward J. Kane and Luc Laeven, "How Country and Safety-Net Characteristics Affect Bank Risk-Shifting”, September 2002.

2002-11 Vidhan K. Goyal and Takeshi Yamada, “Asset Price Shocks, Financial Constraint, and Investment: Evidence from Japan”, September 2002.

2002-12 Clive S. Lennox, “Opinion Shopping and Audit Committees”, September 2002.

2002-13 Seki Obata, “Pyramid Business Groups in East Asia: Insurance or Tunneling?”, September 2002.

2002-14 Ishtiaq Pasha Mahmood and Will Mitchell, “Two Faces: Effects of Business Groups on Innovation in Emerging Economies”, September 2002.

2002-15 Kwangwoo Park, "Foreign Ownership and Firm Value in Japan”, September 2002.

2002-16 Adrian van Rixtel, Yupana Wiwattanakantang, Toshiyuki Souma, and Kazunori Suzuki, “ Banking in Japan: Will “To Big To Fail” Prevail?”, December 2002.

2002-17 Stijn Claessens and Leora F. Klapper, "Bankruptcy around the World: Explanations of its Relative Use", December 2002.

2003-1 Anya Khanthavit, Piruna Polsiri, and Yupana Wiwattanakantang, "Did Families Lose or Gain Control after the East Asian Financial Crisis?”, February 2003.

2003-2 Hidenobu Okuda, Hidetoshi Hashimoto, and Michiko Murakami, "The Estimation of Stochastic Cost Functions of Malaysian Commercial Banks and Its Policy Implications to Bank Restructuring", February 2003.

2003-3 Masaharu Hanazaki and Liuqun, “Asian Crisis and Corporate Governance, (in Japanese)”, March 2003.

2003-4 Fukuju Yamazaki and Hiroyuki Seshita, "Economic Analysis of Bankruptcy law in Japan, (in Japanese)", February 2003.

2003-5 Hirofumi Uchida and Hiroshi Osano, "Bank Monitoring and Corporate Governance in Japan, (in Japanese)", March 2003.

2003-6 Fukunari Kimura and Kozo Kiyota, "Foreign Ownership and Corporate Performance: Evidence from Japanese Micro Data, (in Japanese) ”, March 2003.

2003-7 Yukinobu Kitamura, "Corporate Profit and Debt- Panel Data Analysis of The Japanese Firms in the 1990s, (in Japanese) ", March 2003.

2003-8 Chaiyasit Aunchitworawong, Toshiyuki Soma, and Yupana Wiwattanakantang, "Do Families Control Banks Prevail after the East Asia Financial Crisis? Evidence from Thailand", March 2003. 
2003-9 Junko Maru, Yasuhiro Yonezawa and Yuki Matsumoto, "Corporate Governance by Foreign Investors in East Asia Corporations (in Japanese) ”, March 2003.

2003-10 Sui Qing-yuan, “Declining Firm's Dependence upon Bank Borrowing and Corporate Performance (in Japanese) ”, March 2003.

2003-11 Katsumi Matsuura, "Changes in Ownership Structures and Their Impacts upon Corporate Performance in Japan (in Japanese) ”, March 2003.

2003-12 Kathy S. He, Randall Morck and Bernard Yeung, "Corporate Stability and Economic Growth", May 2003.

2003-13 Robert Dekle and Heajin Ryoo, "Exchange Rate Fluctuations, Financing Constraints, Hedging, and Exports: Evidence from Firm Level Data”, June 2003.

2003-14 Tsun-Siou Lee, Yin-Hua Yeh and Rong-Tze Liu, "Can Corporate Governance Variables Enhance the Prediction Power of Accounting-Based Financial Distress Prediction Models?”, June 2003.

2003-15 Hideaki Miyajima and Yishay Yafeh, "Japan’s Banking Crisis: Who has the Most to Lose?", June 2003.

2003-16 Guifen Pei, “Asset Management Companies in China”, June 2003.

2003-17 Takeshi Nagase, “The Governance Structure of IPO Firm in Japan”, July 2003.

2003-18 Masaharu Hanazaki and Qun Liu, "The Asian Crisis and Corporate Governance Ownership Structure, Debt Financing, and Corporate Diversification —”, July 2003.

2003-19 Chutatong Charumilind, Raja Kali and Yupana Wiwattanakantang, "Connected Lending: Thailand before the Financial Crisis", July 2003.

2003-20 Gilles Hilary and Tomoki Oshika, "Shareholder activism in Japan: social pressure, private cost and organized crime", August 2003.

2003-21 Sanghoon Ahn, “Technology Upgrading with Learning Cost”, September 2003.

2003-22 Masaharu Hanazaki and Akiyoshi Horiuchi, "Have Banks Contributed to Efficient Management in Japan's Manufacturing?”, November 2003.

2003-23 Chongwoo Choe and In-Uck Park, "Delegated Contracting and Corporate Hierarchies", November 2003.

2003-24 Bruno Dallago, "Comparative Economic Systems and the New Comparative Economics: Foes, Competitors, or Complementary?", November 2003.

2003-25 Adrian van Rixtel, Ioana Alexopoulou and Kimie Harada, "The New Basel Capital Accord and Its Impact on Japanese Banking: A Qualitative Analysis”, November 2003.

2004-1 Masaharu Hanazaki, Toshiyuki Souma and Yupana Wiwattanakantang, "Silent Large Shareholders and Entrenched Bank Management: Evidence from Banking Crisis in Japan", January 2004.

2004-2 Ming Ming Chiu and Sung Wook Joh, "Bank Loans to Distressed Firms: Cronyism, bank governance and economic crisis”, January 2004. 
2004-3 Keun Lee, Keunkwan Ryu and Jungmo Yoon, “Corporate Governance and Long Term Performance of the Business Groups: The Case of Chaebols in Korea", January 2004.

2004-4 Randall Morck and Masao Nakamura, "Been There, Done That -The History of Corporate Ownership in Japan", March 2004.

2004-5 Dong-Hua Chen, Joseph P. H. Fan and T. J. Wong, "Politically-connected CEOs, Corporate Governance and Post-IPO Performance of China's Partially Privatized Firms", March 2004.

2004-6 Jae-Seung Baek, Jun-Koo Kang and Inmoo Lee, "Business Groups and Tunneling: Evidence from Private Securities Offerings by Korean Chaebols", March 2004.

2004-7 E. Han Kim, “To Steal or Not to Steal: Firm Attributes, Legal Environment, and Valuation”, March 2004.

2004-8 Yin-Hua Yeh and Tracie Woidtke, "Commitment or Entrenchment?: Controlling Shareholders and Board Composition”, June 2004.

2004-9 Hugh Patrick, “Thoughts on Evolving Corporate Governance in Japan”, June 2004.

2004-10 Utpal Bhattacharya and Hazem Daouk, "When No Law is Better than a Good Law", June 2004.

2004-11 Sanghoon Ahn, Utpal Bhattacharya, Taehun Jung and Giseok Nam, "Do Japanese CEOs Matter?", June 2004.

2004-12 Megumi Suto and Masashi Toshino, "Behavioural Biases of Japanese Institutional Investors; Fund management and Corporate Governance”, July 2004.

2004-13 Piruna Polsiri and Yupana Wiwattanakantang, "Business Groups in Thailand: Before and after the East Asian Financial Crisis", August 2004.

2004-14 Fumiharu Mieno, "Fund Mobilization and Investment Behavior in Thai Manufacturing Firms in the Early 1990s", August 2004.

2004-15 Chaiyasit Anuchitworawong, "Deposit Insurance, Corporate Governance and Discretionary Behavior: Evidence from Thai Financial Institutions”, September 2004.

2004-16 Chaiyasit Anuchitworawong, "Financial fragility under implicit insurance scheme: Evidence from the collapse of Thai financial institutions", September 2004.

2004-17 Chaiyasit Anuchitworawong, “Ownership-based Incentives, Internal Corporate Risk and Firm Performance”, September 2004.

2004-18 Jack Ochs and In-Uck Park, "Overcoming the Coordination Problem: Dynamic Formation of Networks", September 2004.

2004-19 Hidenobu Okuda and Suvadee Rungsomboon, "Comparative Cost Study of Foreign and Thai Domestic Banks 1990-2002: Estimating Cost Functions of the Thai Banking Industry", February 2005.

2004-20 Hidenobu Okuda and Suvadee Rungsomboon, "The Effects of Foreign Bank Entry on the Thai Banking Market: Empirical Analysis from 1990 to 2002 “, March 2005. 
2004-21 Juro Teranishi, "Investor Right in Historical Perspective: Globalization and the Future of the Japanese Firm and Financial System", March 2005.

2004-22 Kentaro Iwatsubo, "Which Accounts for Real Exchange Rate Fluctuations, Deviations from the Law of One Price or Relative Price of Nontraded Goods?", March 2005.

2004-23 Kentaro Iwatsubo and Tomoyuki Ohta, "Causes and effects of exchange rate regimes (in Japanese)", March 2005.

2004-24 Kentaro Iwatsubo, "Bank Capital Shocks and Portfolio Risk: Evidence from Japan”, March 2005.

2004-25 Kentaro Iwatsubo, “On the Bank-led Rescues Financially Distressed Firms in Japan”, March 2005.

2005-1 Yishay P. Yafeh and Tarun Khanna, "Business Groups in Emerging Markets: Paragons or Parasities?", September 2005.

2005-2 Renee B. Adams and Daniel Ferreira, "Do Directors Perform for Pay?," September 2005.

2005-3 Qun Liu, Shin-ichi Fukuda and Juro Teranishi, "What are Characteristics of Financial Systems in East Asia as a Region?", September 2005.

2005-4 Juro Teranishi, "Is the Financial System of Postwar Japan Bank-dominated or Market Based?", September 2005.

2005-5 Hasung Jang, Hyung-cheol Kang and Kyung Suh Park, "Determinants of Family Ownership: The Choice between Control and Performance", October 2005.

2005-6 Hasung Jang, Hyung-cheol Kang and Kyung Suh Park, "The Choice of Group Structure: Divide and Rule", October 2005.

2005-7 Sangwoo Lee, Kwangwoo Park and Hyun-Han Shin, "The Very Dark Side of International Capital Markets: Evidence from Diversified Business Groups in Korea", October 2005.

2005-8 Allen N. Berger, Richard J. Rosen and Gregory F. Udell, "Does Market Size Structure Affect Competition? The Case of Small Business Lending", November 2005.

2005-9 Aditya Kaul and Stephen Sapp, "Trading Activity and Foreign Exchange Market Quality”, November 2005.

2005-10 Xin Chang, Sudipto Dasgupta and Gilles Hilary, "The Effect of Auditor Choice on Financing Decisions", December 2005.

2005-11 Kentaro Iwatsubo, “Adjustment Speeds of Nominal Exchange Rates and Prices toward Purchasing Power Parity", January 2006.

2005-12 Giovanni Barone-Adesi, Robert Engle and Loriano Mancini, "GARCH Options in Incomplete Markets", March 2006.

2005-13 Aditya Kaul, Vikas Mehrotra and Blake Phillips, "Ownership, Foreign Listings, and Market Valuation", March 2006.

2005-14 Ricard Gil, "Renegotiation, Learning and Relational Contracting”, March 2006. 
2005-15 Randall Morck, "How to Eliminate Pyramidal Business Groups -The Double Taxation of Inter-corporate Dividends and other Incisive Uses of Tax Policy-”, March 2006.

2005-16 Joseph P.H. Fan, T.J. Wong and Tianyu Zhang, "The Emergence of Corporate Pyramids in China", March 2006.

2005-17 Yan Du, Qianqiu Liu and S. Ghon Rhee, “An Anatomy of the Magnet Effect: Evidence from the Korea Stock Exchange High-Frequency Data”, March 2006.

2005-18 Kentaro Iwatsubo and Junko Shimizu, "Signaling Effects of Foreign Exchange Interventions and Expectation Heterogeneity among Traders", March 2006.

2005-19 Kentaro Iwatsubo, “Current Account Adjustment and Exchange Rate Pass-Through(in Japanese)", March 2006.

2005-20 Piruna Polsiri and Yupana Wiwattanakantang, "Corporate Governance of Banks in Thailand", March 2006.

2006-1 Hiroyuki Okamuro and Jian Xiong Zhang, "Ownership Structure and R\&D Investment of Japanese Start-up Firms,” June 2006.

2006-2 Hiroyuki Okamuro, "Determinants of R\&D Activities by Start-up Firms: Evidence from Japan,” June 2006.

2006-3 Joseph P.H. Fan, T.J. Wong and Tianyu Zhang, "The Emergence of Corporate Pyramids in China," August 2006.

2006-4 Pramuan Bunkanwanicha, Jyoti Gupta and Yupana Wiwattanakantang, "Pyramiding of Family-owned Banks in Emerging Markets,” September 2006.

2006-5 Bernardo Bortolotti and Mara Faccio, "Reluctant privatization,” September 2006.

2006-6 Jörn Kleinert and Farid Toubal, "Distance costs and Multinationals' foreign activities”, October 2006.

2006-7 Jörn Kleinert and Farid Toubal, “Dissecting FDI”, October 2006.

2006-8 Shin-ichi Fukuda and Satoshi Koibuchi, "The Impacts of "Shock Therapy" on Large and Small Clients: Experiences from Two Large Bank Failures in Japan”, October 2006.

2006-9 Shin-ichi Fukuda, Munehisa Kasuya and Kentaro Akashi, "The Role of Trade Credit for Small Firms: An Implication from Japan’s Banking Crisis”, October 2006.

2006-10 Pramuan Bunkanwanicha and Yupana Wiwattanakantang, "Big Business Owners and Politics: Investigating the Economic Incentives of Holding Top Office”, October 2006.

2006-11 Sang Whi Lee, Seung-Woog(Austin) Kwang, Donald J. Mullineaux and Kwangwoo Park, "Agency Conflicts, Financial Distress, and Syndicate Structure: Evidence from Japanese Borrowers", October 2006.

2006-12 Masaharu Hanazaki and Qun Liu, "Corporate Governance and Investment in East Asian Firms -Empirical Analysis of Family-Controlled Firms”, October 2006.

2006-13 Kentaro Iwatsubo and Konomi Tonogi, "Foreign Ownership and Firm Value: Identification through Heteroskedasticity (in Japanese)”, December 2006. 
2006-14 Kentaro Iwatsubo and Kazuyuki Inagaki, "Measuring Financial Market Contagion Using Dually-Traded Stocks of Asian Firms", December 2006.

2006-15 Hun-Chang Lee, "When and how did Japan catch up with Korea? -A comparative study of the pre-industrial economies of Korea and Japan", February 2007.

2006-16 Kyoji Fukao, Keiko Ito, Shigesaburo Kabe, Deqiang Liu and Fumihide Takeuchi, “Are Japanese Firms Failing to Catch up in Localization? An Empirical Analysis Based on Affiliate-level Data of Japanese Firms and a Case Study of the Automobile Industry in China", February 2007.

2006-17 Kyoji Fukao, Young Gak Kim and Hyeog Ug Kwon, "Plant Turnover and TFP Dynamics in Japanese Manufacturing”, February 2007.

2006-18 Kyoji Fukao, Keiko Ito, Hyeg Ug Kwon and Miho Takizawa, "Cross-Border Acquisitons and Target Firms' Performance: Evidence from Japanese Firm-Level Data”, February 2007.

2006-19 Jordan Siegel and Felix Oberholzer-Gee, "Expropriators or Turnaround Artists? The Role of Controlling Families in South Korea (1985-2003)”, March 2007.

2006-20 Francis Kramarz and David Thesmar, "Social Networks in The Boardroom”, March 2007.

2006-21 Morten Bennedsen, Francisco Pérez-González and Daniel Wolfenzon, “Do CEOs matter?”, March 2007.

2007-1 Ichiro Iwasaki, "Endogenous board formation and its determinants in a transition economy: evidence from Russia*", April 2007, Revised on October 2007.

2007-2 Joji Tokui, Tomohiko Inui, and Katsuaki Ochiai, "The Impact of Vintage Capital and R\&D on Japanese Firms' Productivity", April 2007.

2007-3 Yasuo Nakanishi and Tomohiko Inui, "Deregulation and Productivity in Japanese Industries", April 2007.

2007-4 Kyoji Fukao, "The Performance of Foreign Firms and the Macroeconomic Impact of FDI", May 2007.

2007-5 Taku Suzuki, "The Role of the State in Economic Growth of Post-Communist Transitional Countries", June 2007.

2007-6 Michiel van Leuvensteijn, Jacob A. Bikker, Adrian A.R.J.M. van Rixtel and Christoffer Kok-Sørensen*, "A new approach to measuring competition in the loan markets of the euro area", June 2007.

2007-7 Sea Jin Chang, Jaiho Chung, and Dean Xu, "FDI and Technology Spillovers in China", July 2007.

2007-8 Fukunari Kimura, "The mechanics of production networks in Southeast Asia: the fragmentation theory approach", July 2007.

2007-9 Kyoji Fukao, Tsutomu Miyagawa, Miho Takizawa, "Productivity Growth and Resource Reallocation in Japan", November 2007.

2007-10 YoungGak Kim, “A Survey on Intangible Capital”, December 2007. 
2007-11 Sea-Jing Chang and Jay Hyuk Rhee, "Rapid International Expansion Strategy of Emerging Market Enterprises: The Interplay between Speed and Competitive Risks on International performance", November 2007.

2007-12 Ishtiaq Mahmood, Will Mitchell, and Chi-Nien Chung, "The Structure of Intra-Group Ties: Innovation in Taiwanese Business", January 2008.

2007-13 Kyoji Fukao, Tomohiko Inui, Shigesaburo Kabe and Deqiang Liu, “ An International Comparison of the TFP Levels of Japanese, Korean and Chinese Listed Firms", March 2008.

2007-14 Pramuan Bunkanwanicha and Yupana Wiwattanakantang, “Allocating Risk Across Pyramidal Tiers: Evidence from Thai Business Groups”, March 2008.

2008-1 Rüdiger Fahlenbrach and René M. Stulz, "Managerial Ownership Dynamics and Firm Value", April 2008.

2008-2 Morten Bennedsen, Kasper Meisner Nielsen, and, Thomas Vester Nielsen, "Private Contracting and Corporate Governance: Evidence from the Provision of Tag-Along Rights in an Emerging Market”, April 2008.

2008-3 Joseph P.H. Fan, Jun Huang, Felix Oberholzer-Gee, and Mengxin Zhao, "Corporate Diversification in China: Causes and Consequences", April 2008.

2008-4 Daniel Ferreira, Miguel A. Ferreira, Clara C. Raposo, "Board Structure and Price Informativeness", April 2008.

2008-5 Nicola Gennaioli and Stefano Rossi, "Judicial Discretion in Corporate Bankruptcy”, April 2008.

2008-6 Nicola Gennaioli and Stefano Rossi, "Optimal Resolutions of Financial Distress by Contract", April 2008.

2008-7 Renée B. Adams and Daniel Ferreira, "Women in the Boardroom and Their Impact on Governance and Performance", April 2008.

2008-8 Worawat Margsiri, Antonio S. Melloy, and Martin E. Ruckesz, “A Dynamic Analysis of Growth via Acquisition", April 2008.

2008-9 Pantisa Pavabutra and Sukanya Prangwattananon, "Tick Size Change on the Stock Exchange of Thailand", April 2008.

2008-10 Maria Boutchkova, Hitesh Doshi, Art Durnev, and Alexander Molchanov, "Politics and Volatility", April 2008.

2008-11 Yan-Leung Cheung, P. Raghavendra Rau, and Aris Stouraitis, "The Helping Hand, the Lazy Hand, or the Grabbing Hand? Central vs. Local Government Shareholders in Publicly Listed Firms in China", April 2008.

2008-12 Art Durnev and Larry Fauver, "Stealing from Thieves: Firm Governance and Performance when States are Predatory", April 2008.

2008-13 Kenneth Lehn, Sukesh Patro, and Mengxin Zhao, "Determinants of the Size and Structure of Corporate Boards: 1935-2000”, April 2008. 
2008-14 Ishtiaq P. Mahmood, Hong-Jin Zhu and Edward J. Zajac, "Where Can Capabilities Come From? How the Content of Network Ties Affects Capability Acquisition", April 2008.

2008-15 Vladimir I. Ivanov and Ronald W. Masulis, "Corporate Venture Capital, Strategic Alliances, and the Governance of Newly Public Firms", May 2008.

2008-16 Dick Beason, Ken Gordon, Vikas Mehrotra and Akiko Watanabe, "Does Restructuring Pay in Japan? Evidence Following the Lost Decade", July 2008 (revision uploaded on Oct. 2009).

2009-1 Vikas Mehrotra, Dimitri van Schaik, Jaap Spronk, and Onno Steenbeek, "Creditor-Focused Corporate Governance: Evidence from Mergers and Acquisitions in Japan,” August, 2009.

2009-2 Debin Ma, "Law and Economic Change in Traditional China: A Comparative Perspective," September, 2009.

2009-3 Robert C. Allen, Jean-Pascal Bassino, Debin Ma, Christine Moll-Murata, and Jan Luiten van Zanden, "Wages, Prices, and Living Standards in China, 1738-1925: in Comparison with Europe, Japan, and India," June 2009.

2009-4 Jung-Wook Shim, “The Existence of Nepotism: Evidence from Japanese Family Firms," October 2009.

2009-5 Morten Bennedsen and Kasper Meisner Nielsen, "Incentive and Entrenchment Effects in European Ownership," March 2009.

2009-6 Joseph P.H. Fan, TJ Wong, Tianyu Zhang, "Founder Succession and Accounting Properties," April 2009.

2009-7 Hiroyuki Okamuro, Masatoshi Kato, and Yuji Honjo, "Determinants of R\&D Cooperation in Japanese High-tech Start-ups,” November 2009.

2009-8 Bill Francis, Iftekhar Hasan, Michael Koetter, and Qiang Wu, "The Effectiveness of Corporate Boards: Evidence from Bank Loan Contracting,” November 2009.

2009-9 Allen N. Berger, Iftekhar Hasan and Mingming Zhou, "The Effects of Focus Versus Diversification on Bank Performance: Evidence from Chinese Banks," November 2009.

2009-10 Leonardo Becchetti, Andrea Carpentieri and Iftekhar Hasan, "The Determinants of Option Adjusted Delta Credit Spreads: A Comparative Analysis on US, UK and the Eurozone," November 2009.

2009-11 Luciano I. de Castro and Harry J. Paarsch, "Testing Affiliation in Private-values Models of First-price Auctions Using Grid Distributions,” December 2009.

2009-12 Chulwoo Baek, YoungGak Kim and Heog Ug Kwon, "Market Competition and Productivity after the Asian Financial Crisis: Evidence from Korean Firm Level Data," December 2009. 
2009-13 Jee-Hyeong Park, Stephen J. Spurr, and Sheng-Kai Chang, "A Model of Hierarchical Professionals: Cooperation and Conflict between Anesthesiologists and CRNAs," October 2009.

2009-14 Jee-Hyeong Park, "Enforcing International Trade Agreements with Imperfect Private Monitoring: Private Trigger Strategies and the Possible Role of the WTO,” December 2009.

2009-15 Yuji Honjo, Masatoshi Kato and Hiroyuki Okamuro, "R\&D financing of start-up firms: How much does founders' human capital matter?", March 2010.

2010-1 Sergei V. Ryazantsev, "Migrant Workers from Central Asian Russian Federation”, June 2010.

2010-2 Tue Gørgens, Xin Meng, and Rhema Vaithianathan, "Stunting and Selection Effects of Famine: A Case Study of the Great Chinese Famine," October 2010.

2010-3 Masatoshi Kato and Yuji Honjo, "Heterogeneous Exits: Evidence from New Firms," November 2010.

2010-4 Sung-Jin Cho, Harry J. Paarsch, and John Rust, “Is the 'Linkage Principle' Valid?: Evidence from the Field," November 2010.

2010-5 Jean-Pascal Bassino and Noriko Kato, "Rich and slim, but relatively short Explaining the halt in the secular trend in Japan," November 2010.

2010-6 Robert G Gregory, Dark Corners in a Bright Economy; The Lack of Jobs for Unskilled Men,” December 2010.

2010-7 Masatoshi Kato and Hiroyuki Odagiri, "Development of University Life-Science Programs and University-Industry Joint Research in Japan,” December 2010.

2010-8 Han Hong, Harry J. Paarsch and Pai Xu, "On the Asymptotic Distribution of the Transaction Price in a Clock Model of a Multi-Unit, Oral, Ascending-Price Auction within the Common-Value Paradigm,” January 2011.

2010-9 Tue Gørgens and Allan W"urtz, "Testing a Parametric Function Against a Nonparametric Alternative in IV and GMM Settings," January 2011.

2010-10 Timothy P. Hubbard, Tong Li and Harry J. Paarsch, "Semiparametric Estimation in Models of First-Price, Sealed-Bid Auctions with Affiliation,” January 2011.

2010-11 Yutaka Arimoto, Kentaro Nakajima, and Tetsuji Okazaki, "Agglomeration or Selection? The Case of the Japanese Silk-Reeling Clusters, 1908-1915,” March 2011.

2010-12 Yukiko Abe, "Regional Variations in Labor Force Behavior of Women in Japan," March 2011.

2010-13 Takashi Kurosaki and Hidayat Ullah Khan, "Vulnerability of Microfinance to Strategic Default and Covariate Shocks: Evidence from Pakistan", March 2011. 
2010-14 Fumiharu Mieno, "Foreign Ownership, Listed Status and the Financial System in East Asia: Evidence from Thailand and Malaysia", March 2011.

2010-15 Hidenobu Okuda and Lai Thi Phuong Nhung, "Fundraising Behaviors of Listed Companies in Vietnam: An Estimation of the Influence of Government Ownership", March 2011.

2011-1 Hiroyuki Okamuro and Junichi Nishimura, "Impact of University Intellectual Property Policy on the Performance of University-Industry Research Collaboration", May 2011.

2011-2 Yutaka Arimoto, "Participatory Rural Development in 1930s Japan: The Economic Rehabilitation Movement", July 2011.

2011-3 Yutaka Arimoto, “The Impact of Farmland Readjustment and Consolidation on Structural Adjustment: The Case of Niigata, Japan”, July 2011.

2011-4 Hidayat Ullah Khan, Takashi Kurosaki, and Ken Miura, "The Effectiveness of Community-Based Development in Poverty Reduction: A Descriptive Analysis of a Women-Managed NGO in Rural Pakistan”, September 2011.

2011-5 Jane Harrigan, "Food Security in the Middle East and North Africa (MENA) and sub-Saharan Africa: A Comparative Analysis", September 2011.

2011-6 Machiko Nissanke, "International and Institutional Traps in Sub-Saharan Africa under Globalisation: A Comparative Perspective”, September 2011.

2011-7 Hiroyuki Okamuro and Junichi Nishimura, "Management of Cluster Policies: Case Studies of Japanese, German, and French Bio-clusters", October 2011.

2011-8 Anne Booth, "Growing Public? Explaining the Changing Economic Role of the State in Asia over the 20th Century", December 2011.

2011-9 Jarko FidrmucI, likka KorhonenII, and Ivana BátorováIII, "China in the World Economy: Dynamic Correlation Analysis of Business Cycles”, December 2011.

2011-10 Yutaka Arimoto, Kentaro Nakajima, and Tetsuji Okazaki, "Productivity Improvement in the Specialized Industrial Clusters: The Case of the Japanese Silk-Reeling Industry", December 2011.

2011-11 Masatoshi Kato, Hiroyuki Okamuro, and Yuji Honjo, "Does Founders' Human Capital Matter for Innovation? Evidence from Japanese Start-ups", December 2011.

2011-12 Yoshihisa Godo, “A New Database on Education Stock in Taiwan”, February 2012.

2011-13 Yutaka Arimoto, Narumi Hori, Seiro Ito, Yuya Kudo, and Kazunari Tsukada, "Impacts of an HIV Counselling and Testing Initiative: Results from an Experimental Intervention in South Africa", March 2012.

2011-14 Fumiharu Mieno and Hisako Kai, "Do Subsidies Enhance or Erode the Cost Efficiency of Microfinance? Evidence from MFI Worldwide Micro Data", April 2012. 
2012-1 Youngho Kang and Byung-Yeon Kim, "Immigration and Economic Growth: Do Origin and Destination Matter?", July 2012.

2012-2 Hee-Dong Yang, Christoph Karon, Sora Kang, "To Convert or not to Convert to the Upgraded Version of de-facto Standard Software?", August 2012.

2012-3 Yutaka Arimoto, Takeshi Fujie, and Tetsuji Senda, "Farmers' Debt in 1930's Japan”, October 2012.

2012-4 Kyoji Fukao and Tangjun Yuan, “China’s Economic Growth, Structural Change and the Lewisian Turning Point", November 2012.

2012-5 Jonathan Morduch, Shamika Ravi, and Jonathan Bauchet, "Failure vs. Displacement: Why an Innovative Anti-Poverty Program Showed No Net Impact”, December 2012.

2012-6 Yutaka Arimoto, Seiro Ito, Yuya Kudo, and Kazunari Tsukada, "Stigma, Social Relationship and HIV Testing in the Workplace: Evidence from South Africa", February 2013.

2012-7 Yutaka Arimoto, Shinsaku Nakajima, and Kohji Tomita, "Farmland Consolidation by Plot Exchange: A Simulation-based Approach”, March 2013.

2012-8 Takashi Kurosaki, "Household-level Recovery after Floods in a Developing Country: Evidence from Pakistan”, November 2012.

2012-9 Yuko Mori and Takashi Kurosaki, "Does Political Reservation Affect Voting Behavior? Empirical Evidence from India”, January 2013.

2012-10 Takashi Kurosaki, "Vulnerability of Household Consumption to Floods and Droughts in Developing Countries: Evidence from Pakistan”, March 2013.

2012-11 Takashi Kurosaki and Hidayat Ullah Khan, "Household Vulnerability to Wild Animal Attacks in Developing Countries: Experimental Evidence from Rural Pakistan", March 2013.

2012-12 Ann M. Carlos, Erin Fletcher, and Larry Neal, "Share Portfolios and Risk Management in the Early Years of Financial Capitalism: London 1690-1730”, September 2012.

2012-13 Katsuo Kogure, "Impacts of Institutional Changes in Cambodia under the Pol Pot Regime", March 2013.

2012-14 Jun-ichi Nakamura and Shin-ichi Fukuda, "What Happened to 'Zombie' Firms in Japan?: Reexamination for the Lost Two Decades", March 2013.

2012-15 Vikas Rawal, “Cost of Cultivation and Farm Business Incomes in India”, March 2013.

2013-1 Ryo Kambayashi and Takao Kato, "Good Jobs, Bad Jobs, and the Great Recession: Lessons from Japan's Lost Decade”, June, 2013. 
2013-2 Jonathan Morduch, Shamika Ravi, Jonathan Bauchet, "Substitution Bias and External Validity: Why an Innovative Anti-poverty Program Showed no Net Impact", July 2013. 